\title{
Poultry Coccidiosis-A Concurrent Overview on Etiology, Diagnostic Practices, and Preventive Measures
}

\author{
Shan Randima Nawarathne ${ }^{1}$, Myunghwan $\mathrm{Yu}^{1}$ and Jung Min $\mathrm{Heo}^{2+}$ \\ ${ }^{I}$ Graduate Student, Department of Animal Science and Biotechnology, Chungnam National University, Daejeon 34134, Republic of Korea \\ ${ }^{2}$ Professor, Department of Animal Science and Biotechnology, Chungnam National University, Daejeon 34134, Republic of Korea
}

\begin{abstract}
Coccidiosis is a major parasitic disease in the poultry industry, with great economic implications worldwide. It is a ubiquitous protozoan infection caused by several species of the genus Eimeria (host-specific) that colonize and reproduce in the intestine of birds, ultimately altering the health and performance of the flock. At present, several methods are used to diagnose coccidiosis in poultry, including field and laboratory techniques (intestinal lesion scoring, oocyst counting in feces, and biochemical and molecular diagnosis). Traditionally, diagnosed flocks have been treated either by vaccination to improve the active immunity of the birds against coccidiosis or supplementation of prophylactic anticoccidials to ameliorate the deleterious effects of coccidiosis. However, these methods has certain drawbacks such as vaccine-induced coccidiosis, drug resistance, and residual drug accumulation in the host. Consequently, alternative safe anti-coccidial agents, including the use of phytogenic compounds, have been explored for preventing coccidiosis. Here, we provide a simple overview of the literature on poultry coccidiosis by focusing on the etiology, diagnostic practices, and preventive measures.
\end{abstract}

(Key words: coccidiosis, diagnostic practices, Eimeria, poultry, preventive measures)

\section{INTRODUCTION}

\section{World Broiler Chicken Industry and the Impact of Infectious Diseases}

The broiler chicken industry is one of the foremost and fast-growing active sub-sector in the world agribusiness that pampers global protein nutrition. The consumer perception towards health benefits of chicken meat, low price, convenience in preparation and low religious constraints make the consumption of chicken more popular around the world (Pouta et al., 2010; Wideman et al., 2016; Attia et al., 2017; Petracci et al., 2019). World broiler meat production has been estimated at approximately 90 million tons/year from 21 billion broiler chickens where broiler meat is the dominant meat source that covers $89 \%$ of the total poultry meat production in the world (Blake and Tomley, 2014). It has been forecasted that higher consumer demand for meat products and the accelerated increment of the global human population (the current population of 7.6 billion expected to increase to 9.8 billion by 2050) will increase the global meat consumption exponentially from 330 to 455 million tons per year by 2050 , while broiler chicken will be covered $40 \%$ of the increased demand (Fatoba and Adeleke, 2018; Izar-Tenorio et al., 2020). The United State of America is the world's largest broiler meat producer ( $20 \%$ of global output), annually rear 9 billion broiler chickens and a consequence of USD 65 billion in revenue, then followed by China, Brazil and the European Union respectively (FAO, 2018; Izar-Tenorio et al., 2020). Also, the better feed efficiency of chickens and relatively lower cost of production make broiler meat production more beneficial and more effective even in developing countries that have limited agriculture resources (Chang, 2007).

Broiler health is a vital factor that affects the growth and global competition of the poultry industry along with the cost of production in the present, and also the strategic future of the industry (Hafez and Attia, 2020). In this regard, infectious diseases from several pathogens such as viruses, bacteria, parasites and fungi either as an individual basis (mono-causal) or in combination with different other microorganisms (multi-causal) could hamper the health and productivity of broilers, thus increased mortality (Fatoba and Adeleke, 2018;

† To whom correspondence should be addressed : jmheo@cnu.ac.kr 
Hafez and Attia, 2020). Furthermore, infectious diseases may lead to substantial economic losses through reduced revenues, reduced quantity or quality of meat, and increased costs of medications and labour along with affecting food security and risk to public health through zoonoses (Wubet et al., 2019; Asfaw et al., 2021). Parasitic diseases are proven to cause the most adverse effects namely higher mortality, impaired growth, worsen feed efficiency and anemia of broilers than other bacterial or viral diseases (Ruff, 1999; Kaufman et al., 2007). Besides, the study of Nnadi and George (2010) is well documented that immunosuppression (especially in terms of vaccination) could be developed due to the parasitic infections in broilers.

\section{Parasites and Parasitism of Broiler Chickens}

A living organism that depends on another organism (the host) for nourishment, shelter, protection and reproduction is defined as a parasite and the dynamic association between a host and a parasite is called parasitism (El-Tonsy, 2012; Poulin and Morand, 2014). As a consequence, pathogenic parasites lead to having poor clinical manifestations such as mechanical injuries, impact effects from toxic compounds, deprivation of nutrients and immunosuppression of the host (Taliaferro, 2009; Garcia et al., 2018). Parasites in broiler chickens can be classified into three major groups based on their inhibition as follows (Permin and Hansen, 1998; Table 1):

Table 1. Major parasites of broiler chickens

\begin{tabular}{|c|c|c|}
\hline Parasite group & Parasites & Predilection site \\
\hline Endoparasites & $\begin{array}{l}\text { Protozoa } \\
\text { - Eimeria spp. } \\
\text { - Histomonas meleagridis } \\
\text { Nematodes } \\
\text { - Oxyspirura mansoni } \\
\text { - Syngamus trachea } \\
\text { - Gongylonema ingluvicola } \\
\text { - Tetrameres spp. } \\
\text { - Acuaria hamulosa } \\
\text { - Capillaria spp. } \\
\text { - Dispharynx nasuta } \\
\text { - Amidostomum anseris } \\
\text { - Ascaridia galli } \\
\text { Cestodes } \\
\text { - Raillietina spp. }\end{array}$ & $\begin{array}{l}\text { Small intestine } \\
\text { Caeca, liver } \\
\text { Eye, lacrimal duct } \\
\text { Trachea, lungs } \\
\text { Oesophagus, crop } \\
\text { Proventriculus } \\
\text { Gizzard } \\
\text { Entire intestine } \\
\text { Erythrocytes, proventriculus } \\
\text { Gizzard } \\
\text { Small intestine, occasionally oviduct } \\
\text { Small intestine }\end{array}$ \\
\hline Ectoparasites & $\begin{array}{l}\text { The fowl tick } \\
\text { - Argas persicus } \\
\text { Mites } \\
\text { - Dermanyssus gallinae } \\
\text { - Ornithonyssus sylviarum } \\
\text { - Cnemidocoptes mutans } \\
\text { Flea } \\
\text { - Echidnophaga gallinacea }\end{array}$ & $\begin{array}{l}\text { Skin } \\
\text { Skin } \\
\text { Skin } \\
\text { Skin on legs, comb and wattle } \\
\text { Head }\end{array}$ \\
\hline Haemoparasites & $\begin{array}{l}\text { - Leucocytozoon spp. } \\
\text { - Plasmodium spp. } \\
\text { - Haemoproteus spp. } \\
\text { - Aegyptinella spp. }\end{array}$ & $\begin{array}{l}\text { Leucocytes, erythrocytes } \\
\text { Erythrocytes } \\
\text { Erythrocytes } \\
\text { Erythrocytes }\end{array}$ \\
\hline
\end{tabular}

Adapted from Permin and Hansen (1998). 
1. Endoparasites (Parasites that inhibit within the body of the host)

2. Ectoparasites (Parasites that inhibit the outside/external surface of the body of the host)

3. Haemoparasites (Parasites that inhabit the bloodstream of the host)

\section{Poultry Coccidiosis; The History and Impact on the Industry}

Coccidiosis is the most catastrophic and commonly encountered parasitic disease in the poultry and the infection by parasites (coccidia) in an adequate number to produce clinical manifestations of the disease is called coccidiosis (Conway and McKenzie, 2007; Sharman et al., 2010; Lawal et al., 2016; Ali et al., 2019; Kim et al., 2019). Poultry coccidiosis has been studied for over a century and the first identification of coccidiosis as a parasitic disease by several species of Eimeria was published in 1910 (Reid, 1990). In the late 1920s and early 1930s, fundamental studies were initiated to study the life cycle and pathogenicity of Eimeria spp. and invent vaccines and chemical medications to control coccidiosis. The USA has introduced prophylactic ionophores antibiotics and started a study to invent a safe vaccine (launched 20 years later) during the 1970s (Shirley and Lillehoj, 2012).

This enteric disease can be found globally in all segments of the poultry industry (i.e., broilers, layers, breeders) and it has been estimated of exceeding USD 3 billion economic impact, annually, due to the production losses and cost for prevention, nutrition, and medications (Blake and Tomley, 2014; Shivaramaiah et al., 2014). Eimeria infection intimidates broiler health and welfare by invading the gut epithelial cells and causes tissue damages (enteritis), interruption to the digestion process and nutrient absorption thus poor feed efficiency (Yegani and Korver, 2008; Soutter et al., 2020). Moreover, coccidiosis leads infected broilers to have bloody diarrhoea, delayed sexual maturity, and eventually higher morbidity and mortality rates (especially young broilers; the age of 3-18 weeks) (Dakpogan and Salifou, 2013; Abdisa et al., 2019).

\section{ETIOLOGY OF COCCIDIOSIS IN CHICKENS}

Coccidiosis in chickens is caused by intracellular apicomplexan protozoan parasites belonging to the genus Eimeria and are frequently vulnerable to seven species of coccidia (Conway and McKenzie, 2007; Fig. 1). All the Eimeria spp. are host-specific (ubiquitous) and each species infects a certain site of the intestinal tract of chickens with different levels of pathogenicity (Table 2) (De Gussem, 2007; Abdisa et al., 2019). As has been previously reported in the literature of Hadipour et al. (2011) and Gharekhani et al. (2014), coccidiosis can be only transpired in an individual host after the ingestion of sporulated oocysts of Eimeria spp. that have been shed by either clinically infected or recovered birds through their faeces, which contaminate feed, water, bedding, and mechanical carriers (i.e., equipment, clothing, insects, farmworkers etc.).

\section{Eimeria spp. Oocyst}

Oocyst is a solid and robust structure (resistant to mechanical, chemical and proteolytic degradations) made by

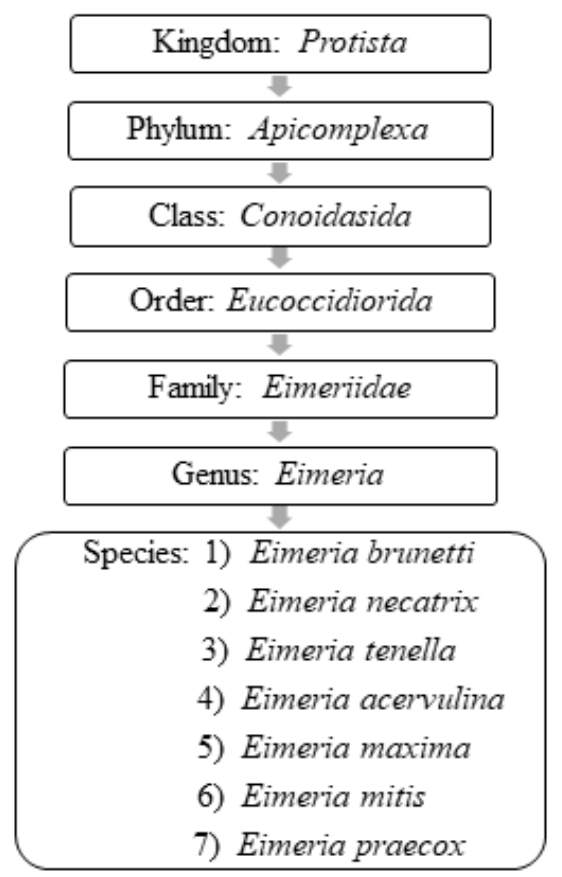

Fig. 1. Taxonomy of Eimeria spp. in chickens (Adapted from Conway and McKenzie, 2007). 
Table 2. Predilection sites of the Eimeria infections and its pathogenicity

\begin{tabular}{lcc}
\hline \hline \multicolumn{1}{c}{ Species } & Predilection site of the intestinal tract & Level of pathogenicity \\
\hline Eimeria brunetti & Caeca and rectum & High \\
Eimeria necatrix & Jejunum, ileum and caeca & High \\
Eimeria tenella & Caeca & High \\
Eimeria acervulina & Duodenum and ileum & Medium \\
Eimeria maxima & Jejunum and ileum & Medium \\
Eimeria mitis & Ileum & Low \\
Eimeria praecox & Duodenum and jejunum & Low \\
\hline
\end{tabular}

Adapted from Conway and McKenzie, 2007; Quiroz-Castañeda and Dantán-González, 2015.

encapsulating the soft bodies of parasites from a glycoprotein and lipid bilayer wall (oocyst wall) that can be preserved/survived in the outer environment for a prolonged/lengthy-time period even under extreme conditions (Mai et al., 2009; Remmal et al., 2011). Based on the infectious ability there are two types of oocysts (Belli et al., 2006; Lal et al., 2009):

1. Unsporulated oocysts (Non-infective)

2. Sporulated oocysts (Infective)

The sporulated oocyst can be survived approximately for 50 months in the external environment (i.e., faeces, litter, feed, soil) until entering a host, whereas, unsporulated oocysts persist for 7 months in the host caecum (Blake and Tomley, 2014; Fatoba and Adeleke, 2018). Unsporulated oocysts can be converted into sporulated oocysts with the presence of favourable conditions (i.e., $\mathrm{O}_{2}$, moisture and warmth) and this process is known as sporulation (Canning, 1968; Quiroz-Castañeda and Dantán-González, 2015). Sporulated Eimeria oocyst (Fig. 2) is comprised of four sporocysts and each of them containing two convex/bananashaped sporozoites which are considered as the infectious stage (Belli et al., 2006; López-Osorio et al., 2020). These oocysts are shed through the faecal materials from infected birds and the coccidia infection can occur after the ingestion of oocysts by a susceptible chicken (Gharekhani et al., 2014; Shivaramaiah et al., 2014). The amount of ingested sporulated oocysts determine the severity of the intestinal damage of the bird (Charlton et al., 2006; Fatoba and
Adeleke, 2018).

\section{Eimeria spp. Life Cycle}

The life cycle of an organism is defined as the sequence of sudden developmental (maturation) changes in the morphology and/or ecology of that particular organism (Benesh, 2016). Eimeria spp. have a homoxenous complex life cycle (Fig. 3) that comprises of two developmental stages namely the exogenous phase (occurs in the outer environment; sporogony) and the endogenous phase (occurs in the intestine of the host; schizogony and gametogony) (Allen and Fetterer, 2002; López-Osorio et al., 2020).

In the exogenous phase, unsporulated oocysts get sporulated by completing miosis and mitosis to produce haploid sprozoites under favourable conditions within 24-48 hours (Shirley and Harvey, 1996; Pattison et al., 2007). The mechanical and chemical (i.e., trypsin, bile salt, carbon dioxide) degradation of the gut liberates the sporozoites (Fig. 4) and they invade the epithelial cells in a specific site of the intestine according to the species involved. After the invasion, sporozoites converts into a feeding stage named trophozoites (12-48 hours), trophozoites get enlarged and asexually multiply/divide the parasite nucleus to complete the schizogony phase (Conway and McKenzie, 2007; Pattison et al., 2007). During a couple of schizogony cycles (number of cycles determined genetically depending on the species) trophozoites generate a large number of merozoites that infect the new cells in both the small and large intestine (Allen and Fetterer, 2002; Blake et al., 2020). Matured merozoites undergo a single round of 


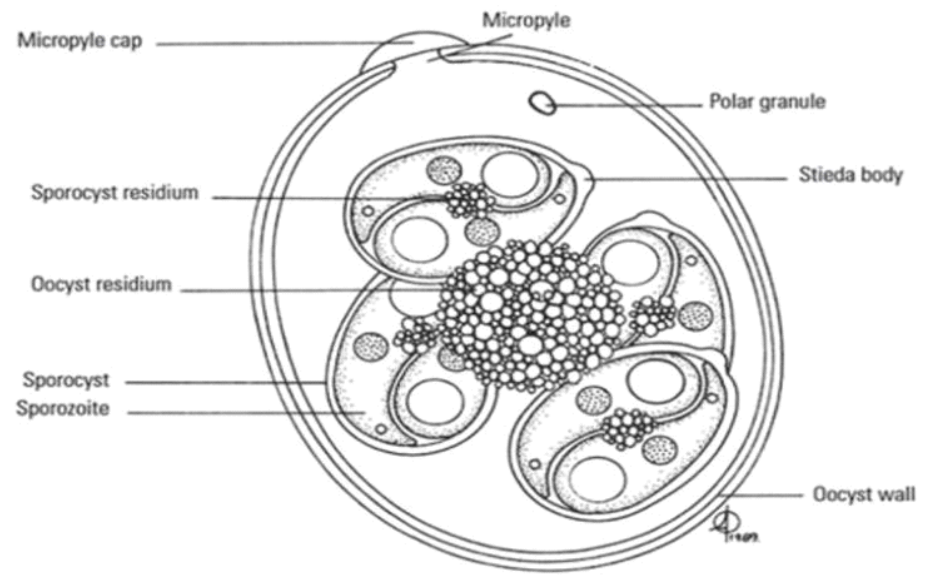

(a)

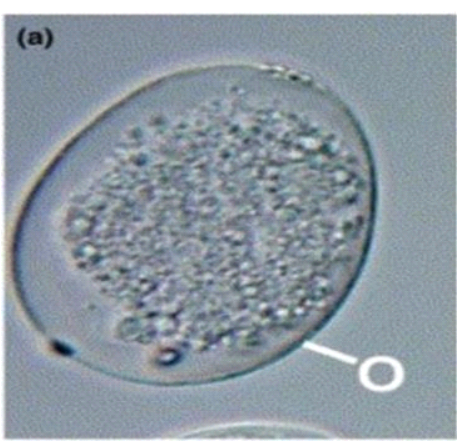

(b)

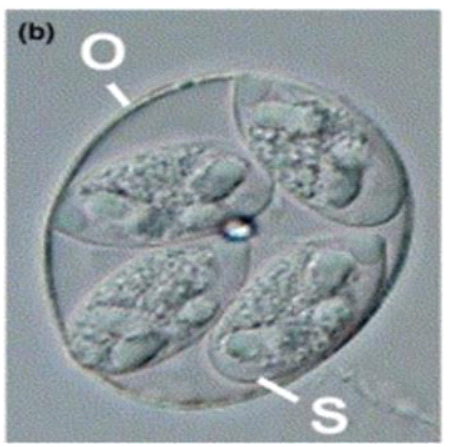

(c)

Fig. 2. Oocyst of Eimeria spp. (a) Composite line drawing of sporulated oocyst of Eimeria spp., (b,c) a; Unsporulated oocysts of Eimeria spp., b; Sporulated oocysts of Eimeria spp. (Retrieved from Levine, 1973 and Belli et al., 2006).

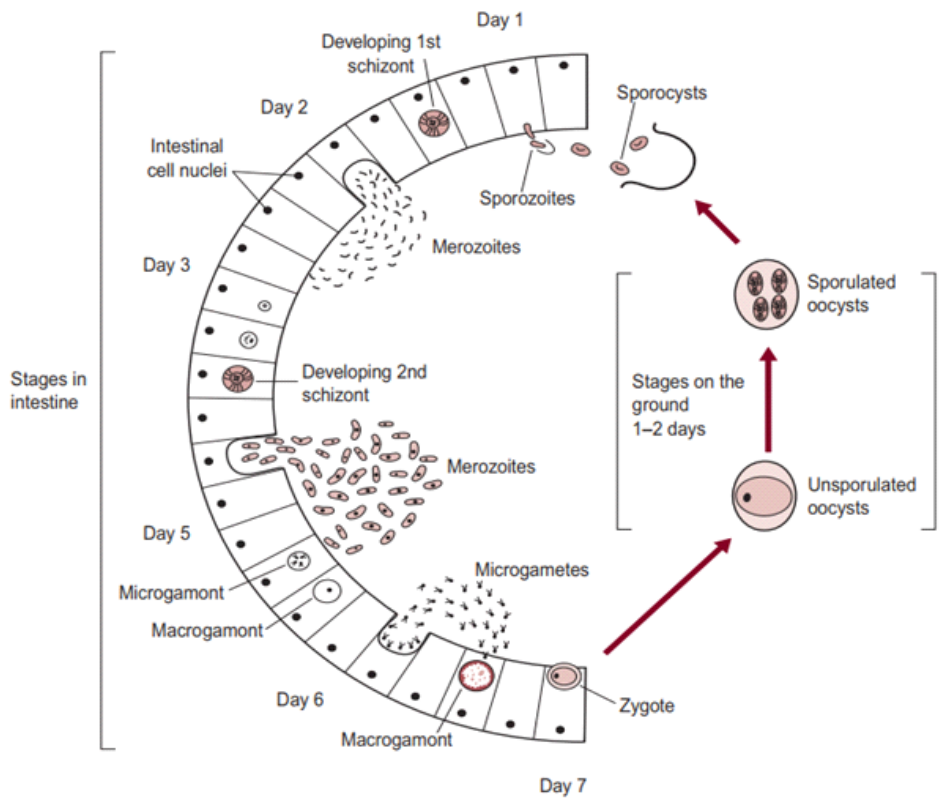

Fig. 3. Typical life cycle of genus Eimeria (Retrieved from Pattison et al., 2007). 


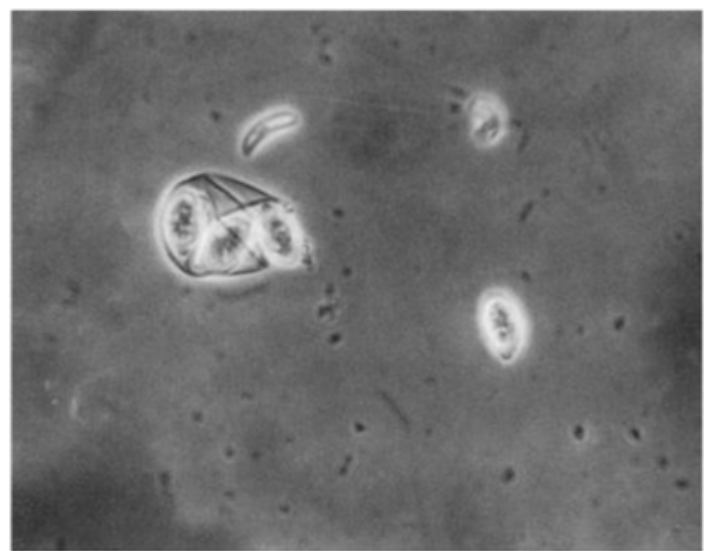

Fig. 4. Release of sporozoites (Retrieved from Conway and McKenzie, 2007).

sexual gametogony phase that resulting in the formation of male microgametes and female macrogametes, and both of these gametes (Fig. 5) are responsible for the clinical signs of coccidiosis such as lesions, imbalance nutrient absorption and diarrhoea (Levine, 1973; Deplazes et al., 2016). Finally, microgametes are surrounded by macrogametes (fertilize), developing the oocysts and are released into the faeces through ruptures of epithelial cells (Deplazes et al., 2016; López-Osorio et al., 2020).

\section{Pathogenicity of Eimeria spp.}

Pathogenicity aggravates with the increasing number of sporulated oocysts ingested by the host and the species of the Eimeria (see Table 2) (Morris and Gasser, 2006; Répérant et al., 2012). Eimeria infection extensively destructs the

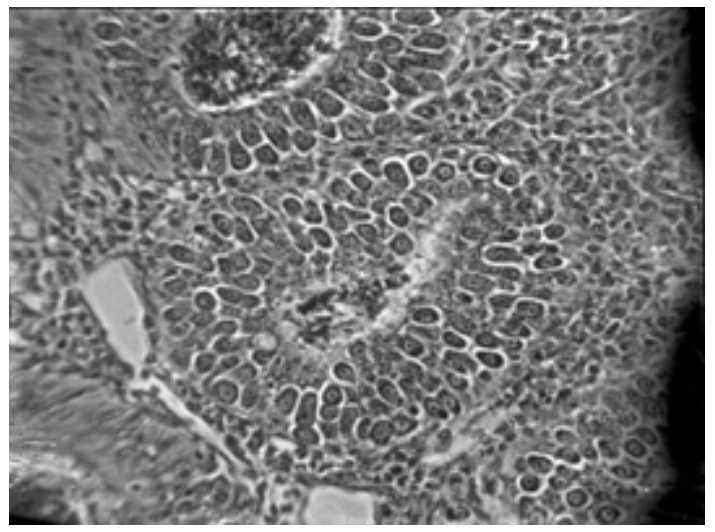

Fig. 5. Eimeria tenella gametocytes (Retrieved from Conway and McKenzie, 2007). intestinal epithelial cells and tissues, thus suppresses the gut stability of chickens (Chen et al., 2020). Consequently, it may lead to impaired digestion of feed and nutrient absorption of chickens, altered serum protein and electrolyte levels with disturbed ion and osmotic balance of gut epithelium (Fitz-Coy and Edgar, 1992). Moreover, it has been found that the Eimeria spp. change the overall structure of the intestinal microbiota and facilitates the growth of other pathogenic bacteria species (i.e., Clostridium perfringens, Salmonella enterica and Campylobacter jejuni) in the gut due to the tissue damages, thus it will impair the gut health and morphology of chickens (Collier et al., 2008; Macdonald et al., 2019). Besides, coccidiosis reduces the caecal microbial diversity, thus alter the production of short-chained fatty acid in the caeca of the chicken (Stanley et al., 2014). The immunity suppression caused by other diseases may exacerbate coccidiosis conditions of birds, for instance, Marek's disease elevates the severity of coccidiosis in broilers (Abebe and Gugsa, 2018).

\section{Clinical Symptoms of Coccidiosis}

Coccidiosis of chickens can occur in two forms as sub-clinical coccidiosis and clinical coccidiosis (Abebe and Gugsa, 2018). Worsen feed efficiency, reduced growth rate, and ultimately higher mortality and morbidity rates can be observed in sub-clinical coccidiosis (Dakpogan and Salifou, 2013; Abdisa et al., 2019). Chickens with clinical coccidiosis exhibit drooping eyelids/somnolence, ruffled feathers, pale colour comb, wattles and internal organs (due to the blood losses), reduced head size, loss of yellow colour in shanks and beak, catarrhal inflammation and dehydration along with haemorrhagic faeces (Graat et al., 1996; Simon, 2005). The study of Singla and Gupta (2012) has reported that some clinical signs of coccidiosis can be confused with other diseases in chickens, therefore further diagnosis methods are required to confirm the coccidiosis in chickens. (Fig. 6, 7, 8)

\section{DIAGNOSTIC METHODS FOR COCCIDIOSIS}

\section{Lesion Scoring (Johnson and Reid method)}

Joyce Johnson and W. Malcolm Reid have developed a 


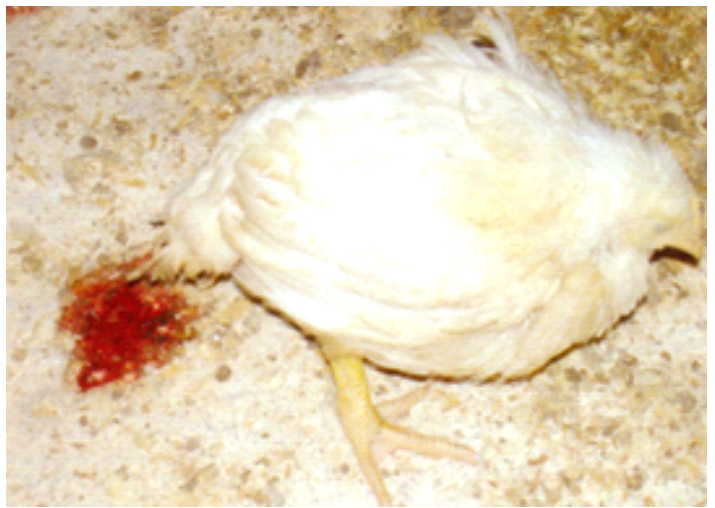

Fig. 6. Bloody diarrhoea (Retrieved from Dinev, 2007).

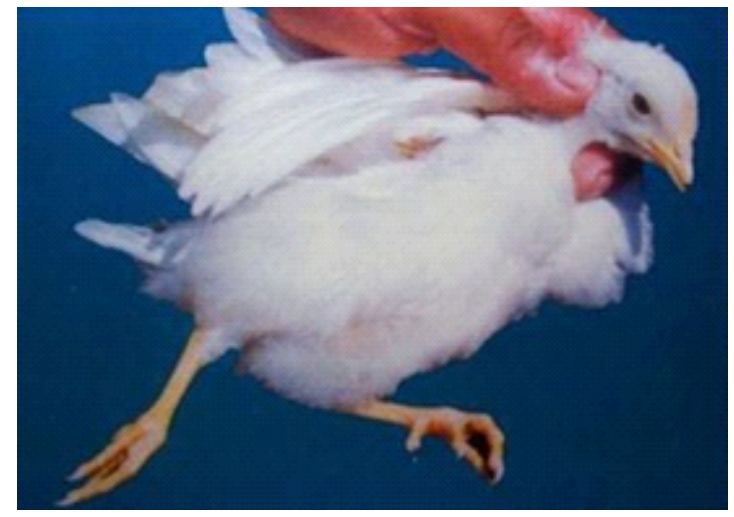

Fig. 7. Yellowish discoloration of shanks and beak (Retrieved from Vegad, 2007).

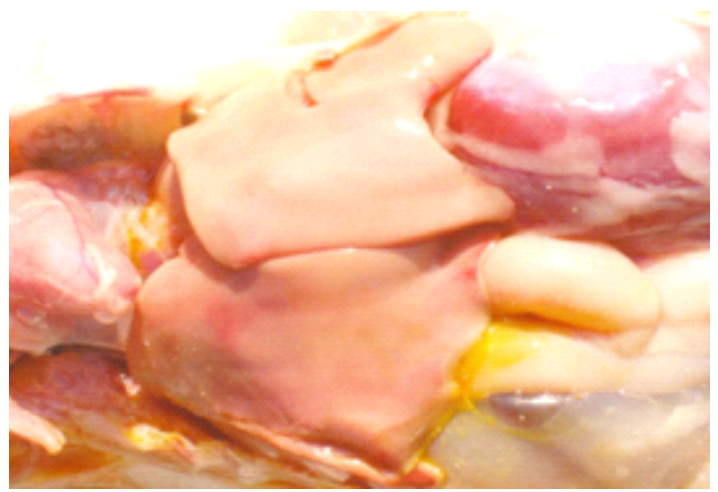

Fig. 8. Anaemic appearance of the internal organs (Retrieved from Dinev, 2007).

post-mortem examination scoring system which ranked from 0 to +4 (i.e., $0=$ no lesion, $+1=$ mild lesion, $+2=$ moderate lesion, $+3=$ severe lesion, $+4=$ extremely severe lesion) to interpret the severity of poultry coccidiosis based on macroscopically visible lesions in the gut caused by Eimeria spp. (Table 3; Fig. 9). The responsible Eimeria species can be identified by examining the predilection site (since species are site-specific; see Table 4) of the intestine and the score is being given based on the extent of the gross lesion (Singla and Gupta, 2012). The complete intestine (between gizzard and rectum) should be dissected and carefully observed the mucosal surface and serosal surface for lesions under a bright light source, nonetheless microscopic observations are required to check smears taken from susceptible lesions for Eimeria parasites when lesions are not visible clearly (Conway and McKenzie, 2007). The individual lesions scores obtained from a discrete bird for all Eimeria species are generally summed for a considered number of birds to have a total mean lesion score (De Gussem, 2007). However, this method is extremely time-consuming, labour intensive, subjective and need a higher level of expert knowledge (Shirley et al., 2005). Johnson and Reid's method is more accurate in diagnosing the coccidiosis in chickens for controlled experimental infections rather than actual farming conditions, where the Eimeria spp. and the dose of oocysts are known (McDougald and Fitz-Coy, 2008).

\section{Quantitative and Qualitative Faecal Examinations}

Eimeria oocysts which are excreted through the faeces of infected birds can be detected by faecal examination methods and are the most convenient and inexpensive ways for diagnosing coccidiosis in chickens (Mwale and Masika, 2011). Either way of microscopic observation of oocysts in smears made from emulsified faeces or check the concentration/amount of floated oocysts by floatation technique is the common qualitative faecal examination diagnosing methods for coccidiosis in chickens (Johnson, 1938; Alqomsan, 2010). A solution with a higher specific gravity (i.e., Saturated sodium chloride, 1.19; saturated glucose, 1.44) is used to float the comparatively low specific gravity (1.05-1.15) oocysts to the surface and leave other debris in faeces at the bottom of the solution (Olanrewaju and Agbor, 2014).

A quantitative faecal examination is performed to determine the number of oocysts per gram of faeces (OPG count) along with the percentage of sporulation and oocyst dimensions (Singla and Gupta, 2012). Particularly two methods are followed to enumerate oocysts as follows 
Table 3. Johnson and Reid method; Scoring system for lesions caused by Eimeria tenella

\begin{tabular}{ll}
\hline \hline \multicolumn{1}{c}{ Score } & Description \\
\hline 0 & No gross lesions \\
+1 & The absence of thickening caecal walls with few scattered petechiae, normal caecal content can be seen \\
+2 & $\begin{array}{l}\text { Moderately thickening of caecal walls, Numerous lesions can be observed with detectable blood in the caecal } \\
\text { content }\end{array}$ \\
& $\begin{array}{l}\text { Higher thickening of caecal walls, High amount of blood and caecal cores, Absence of normal caecal contents and } \\
\text { the serosa of the unopened caeca shows the petechia on the entire surface }\end{array}$ \\
& $\begin{array}{l}\text { Greatly thickening of caecal walls, the caeca are distended with a large amount of blood and caecal cores combined } \\
\text { with faecal debris, the distal end of caeca get shrunken and ruptured, dead birds also scored }+4\end{array}$ \\
\hline
\end{tabular}

Adapted from Johnson and Reid, 1970.

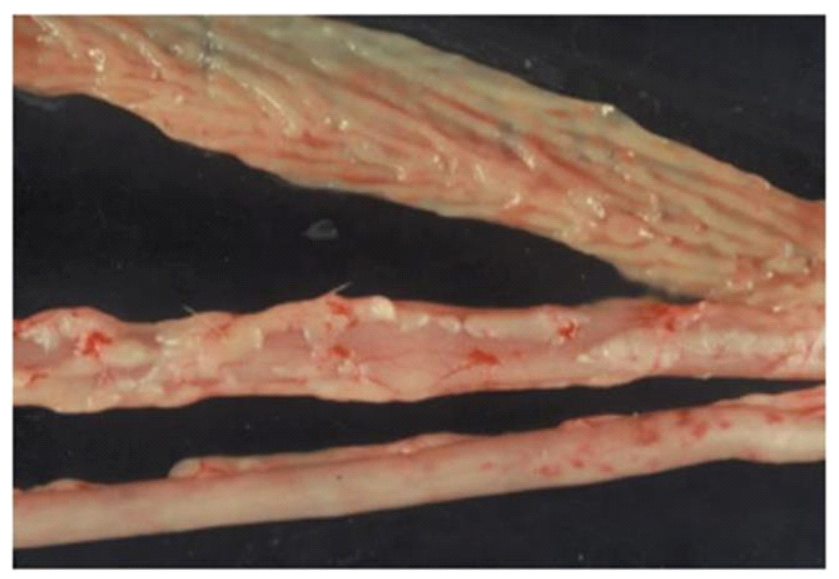

(a)

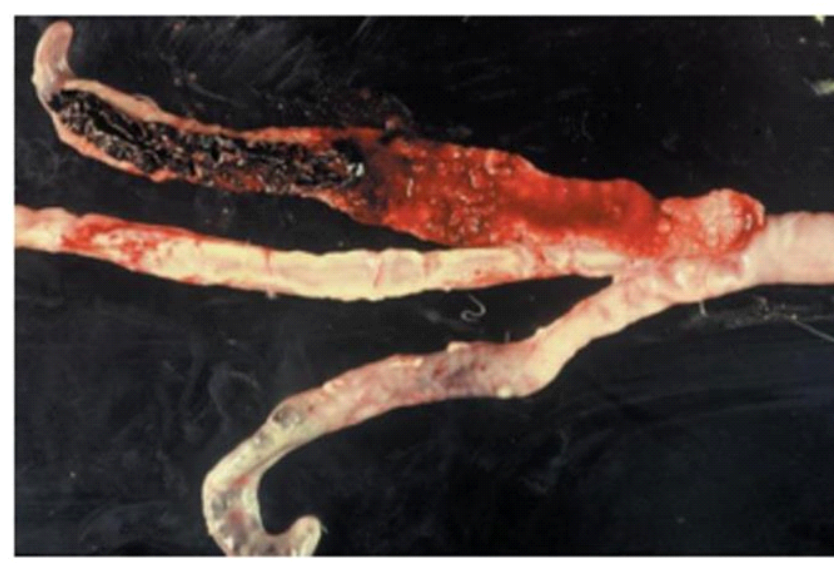

(c)

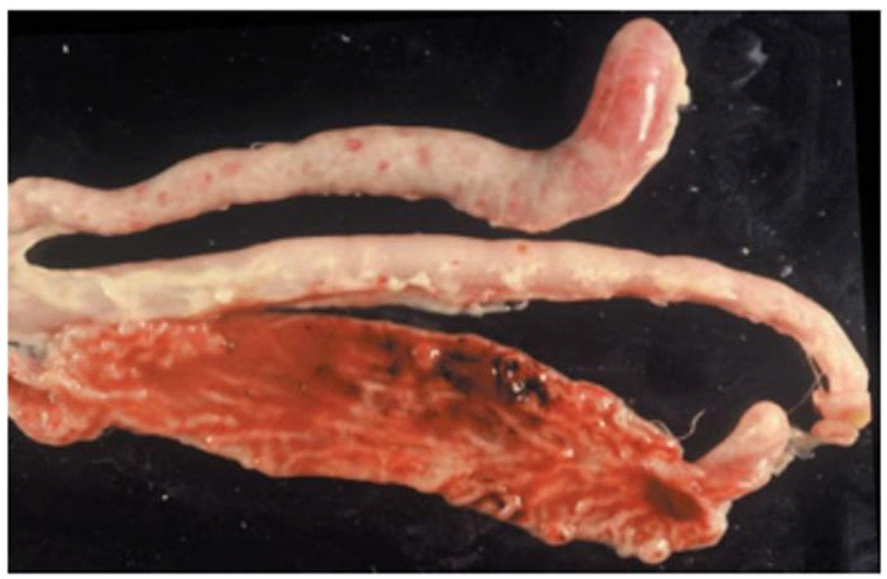

(b)

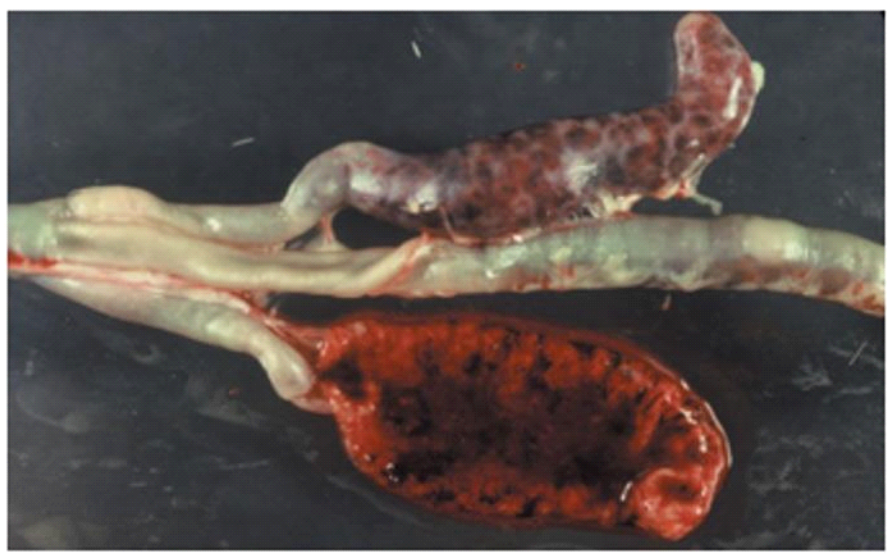

(d)

Fig. 9. Scoring atlas of lesions caused by Eimeria tenella; (a) Eimeria tenella +1 ; (b) Eimeria tenella +2 ; (c) Eimeria tenella +3 ; (d) Eimeria tenella +4 ; (Retrieved from Conway and McKenzie, 2007). 
Table 4. Condition of lesions caused by Eimeria infections and its predilection sites

\begin{tabular}{|c|c|c|}
\hline Eimeria species & Predilection site & Condition of the lesion \\
\hline Eimeria brunetti & The lower half of the intestine & $\begin{array}{l}\text { Thin-walled intestine, mucoid on necrotic discharge, distension } \\
\text { of the intestine. }\end{array}$ \\
\hline Eimeria necatrix & Middle intestine & $\begin{array}{l}\text { Severe haemorrhage with mucoid discharge whitish and red } \\
\text { spot in the wall of the intestine. }\end{array}$ \\
\hline Eimeria tenella & Caeca & $\begin{array}{l}\text { Severe haemorrhage with white red spots in the wall of the } \\
\text { intestine. }\end{array}$ \\
\hline Eimeria acervulina & Upper intestine & $\begin{array}{l}\text { Whitish spots on the wall on serous surface haemorrhage } \\
\text { streak and whitish lesions on the intestinal surface, mucoid } \\
\text { enteritis. }\end{array}$ \\
\hline Eimeria maxima & Middle intestine & Distended intestine with haemorrhage spots, mucoid discharge. \\
\hline Eimeria praecox & Duodenum & $\begin{array}{l}\text { No lesion but slightly haemorrhagic appearance on the } \\
\text { intestinal surface of duodenum slight mucoid discharge. }\end{array}$ \\
\hline
\end{tabular}

Adapted from Abebe and Gugsa, 2018.

(Conway and McKenzie, 2007):

1. McMaster chamber method

2. Hemocytometer method

McMaster method is the most common laboratory analysis technique for counting Eimeria oocysts in the faecal solution and for determining the individual oocysts shedding pattern of an infected bird (Kaufmann, 1996). The floatation method of oocysts is identical to the quantitative technique and it takes place in a special counting chamber/slide known as the McMaster slide (Fig. 10) to facilitate easy counting through the light microscope (Vadlejch et al., 2011). Notwithstanding, a higher level of expert knowledge is required to distinguish

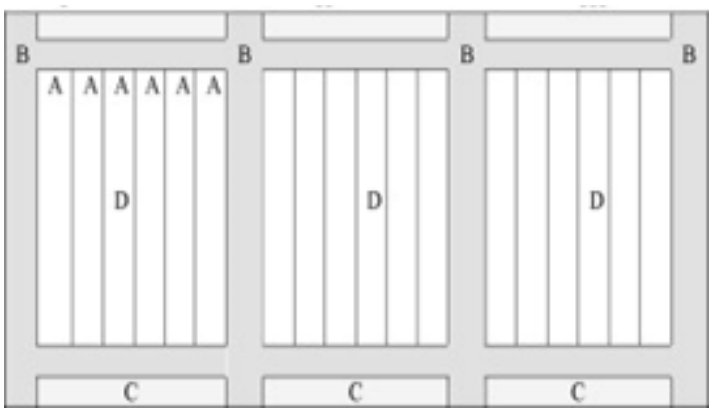

Fig. 10. McMaster chamber design: (A) ruled lines of the chamber; (B) supporting strips; (C) platforms; (D) three sections. (Retrieved from Pereckienè et al., 2007). the Eimeria spp. based on their morphology through the McMaster method and OPG count does not elaborate on the negative effect of the Eimeria parasite on the performance of the flock (De Gussem, 2007).

The Hemocytometer method has been used to estimate the cell concentration in a sample that is adopted for computing the coccidia oocysts in faecal solution by using a hemocytometer (Absher, 1973; Conway and McKenzie, 2007). A common preliminary solution preparation method is shared with the McMaster method and the sample being loaded into a special counting slide, Neubauer chamber/ hemocytometer slide (Fig. 11) that consisted of a $0.1 \mathrm{~mm}$ deep chamber with

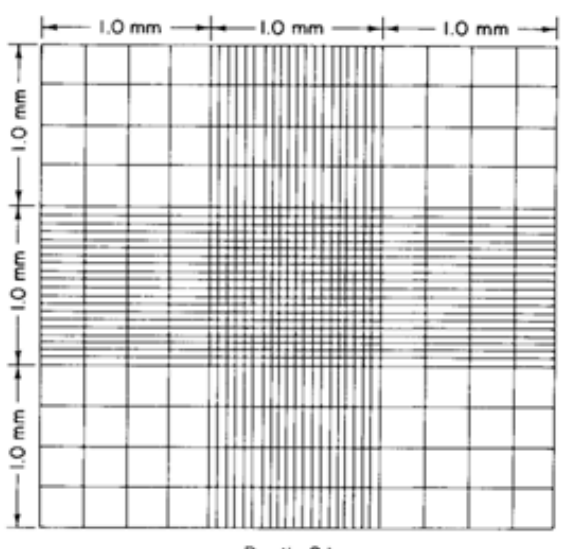

Depth $0.1 \mathrm{~mm}$

Fig. 11. Neubauer type hemocytometer chamber design (Retrieved from Absher, 1973). 
a square grid and observe through the light microscope (Arabkhazaeli et al., 2011; Abunemeh, 2016). The Hemocytometer method handily distinguishes Eimeria oocysts, nonetheless, the counting error per millilitre is higher rather than the McMaster method (Conway and McKenzie, 2007).

\section{Biochemical and Molecular Diagnostic Methods}

Next-generation laboratory diagnostic methods are indispensable over the aforementioned traditional methods to identify the exact Eimeria spp. responsible for the infection with regards to prevention and control of the coccidiosis (Fatoba and Adeleke, 2018). Besides, the limitations of traditional methods can be overcome by following laboratorydeveloped diagnostic methods and are species-specific with a higher rate of sensitivity and accuracy (Singla and Gupta, 2012). The enzyme-linked immunosorbent assay (ELISA) is a straightforward and reliable biochemical diagnostic method for coccidiosis that detects epitope-specific antibodies (IgG and IgM) of Eimeria spp. presents in the serum (Smith et al., 1993; Constantinoiu et al., 2007). Moreover, Onaga et al. (1986) reported that ELISA can be used to determine the degree of exposure of Eimeria spp. to a flock and the exposure rate of vaccinated chickens (infectivity in vaccination programs). Even so, results of the ELISA can be impaired due to the cross-reactivity of antibodies that can be observed for multiple Eimeria spp. sporozoites and merozoites in chicken serum (Uchida et al., 1994).

Polymerase chain reaction (PCR) is a highly sensitive molecular diagnostic technique that is used to identify the Eimeria spp. in chickens by examining their variations of genomic DNA (Schnitzler et al., 1998; Alqomsan, 2010). Amplification and identification of excised internal transcribed spacer 1 and 2 (ITS-1 and ITS-2) regions of ribosomal DNA (rDNA) are being practised in PCR, since it has been proven that, the particular region is divergent in between Eimeria spp. and it gives accurate results (Lew et al., 2003; Hamidinejat et al., 2010; Fatoba and Adeleke, 2018). Specific sets of primers and species-specific PCR assays are developed in the present to distinguish five Eimeria spp. namely E. tenella, E. maxima, E. acervulina, E. necatrix, and
E. brunetti (Su et al., 2003). Moreover, conserved ribosomal DNA sequences (i.e., 5.8S and 28S) targeting method can be practised to identify the Eimeria spp. in chickens and instead of ITS-1 and ITS-2, Random Amplified Polymorphic DNA (RAPD) is used to develop Sequence Characterized Amplified Region (SCAR) primers for the identification of individual Eimeria species (Fernandez et al., 2003; Cantacessi et al., 2008).

The multi-locus enzyme electrophoresis (MEE) method is followed to individually determine the Eimeria strains in a sample (Morris and Gasser, 2006; Singla and Gupta, 2012). Different strains of Eimeria have unique varieties of enzymes and those enzymes are being separated based on the migration distance through a gel base under the influence of an electric field according to their charge and size (Andrews and Chilton, 1999). By analysing the relative positions of an enzyme, the particular enzyme and the Eimeria spp. who owns that enzyme can be predicted.

Southern blot analysis is also an electrophoresis technique that detects specific/unique fragments of DNA of different Eimeria stains that results from the digestion of genomic DNA by restriction endonucleases (Morris and Gasser, 2006; Singla and Gupta, 2012). Hybridization (using radiolabelled probs) and either autoradiography or fluorography are followed after the electrophoresis to detect the relative position of the species-specific DNA fragments (Ellis, 1990; Morris and Gasser, 2006).

\section{CONTROLLING MEASURES OF COCCIDIOSIS}

\section{Good Management and Bio-Security}

It is challenging to keep chickens free from coccidiosis due to the omnipresent nature, higher spreading ability and higher reproduction ability of coccidia oocysts (Allen and Fetterer, 2002). Therefore, all the management and biosecurity practices should be targeted to prevent the entry of the coccidia parasites into the farm and/or if the infection already takes place, suppress the multiplication of parasites and the spread of the disease (Peek and Landman, 2011). Cleaning and disinfection of the farm premises between every two 
flocks are crucial in controlling coccidiosis. Many disinfecting agents such as ammonium hydroxide (both fluid and vapour form; concentration of $\geq 5 \%$ ), cresol-based products, a combination of formol (37\%) and sodium dodecylbenzene sulphonate (12\%), and a combination of calcium hydroxide and ammonium sulphate have been identified and used globally for destroying sporulated and non-sporulated oocysts (Peek and Landman, 2011). Due to the possibility of spreading coccidiosis through contaminated litter from excreted oocysts, the litter should be always maintained dry, frequently raked and replace between every two flocks (it suppress the sporulation of oocysts) and also lime powder can be used as a litter drying agent in the rainy seasons (Shivaramaiah et al., 2014; Abdisa et al., 2019). Moreover, separation of the chickens from the external environment, reduction of risky movements in the farm and in between farms, sanitation of the persons and pieces of equipment, proper ventilation, reduction of bird density in the farm and supplementation of clean feed and drinking water can be followed generally to prevent coccidiosis outbreaks in broiler farms (Williams et al., 2000; Peek and Landman, 2011; Quiroz-Castañeda and Dantán-González, 2015).

\section{Vaccination}

Chickens are capable of acquiring active immunity and/or passive immunity against poultry coccidiosis to ameliorate its deleterious effects (Lee et al., 2009; Wallach, 2010). The active immunity is provoked by intended infections of either Eimeria oocysts or live parasites (as a mixture of multiple Eimeria spp. and/or strains of virulent or attenuated parasites), which can be persistent and highly specific for the Eimeria spp. (Chapman, 1999; Allen and Fetterer, 2002). Despite the cost and more workforce, vaccination is being identified as the best strategy for controlling coccidiosis in chickens for a long time, which can be practised as follows (Fanatico, 2006; Chapman and Jeffers., 2014; Sokale et al., 2017; Albanese et al., 2018):

1. Spray the vaccine on the feed

2. Mix the vaccine with drinking water

3. Spray cabinet method - Apply through a water-based spray in hatcheries for day-old chicks, ingestion of oocysts can be happened from preening and through their eyes, only $90-95 \%$ of chicks will be received the vaccine.

4. Vaccine incorporated edible gel pucks (Fig. 12) - Can be placed inside the house or in transport crates, could be bright in colour to attract chicks, homogeneity of the vaccine in the gel can be less.

5. In-ovo injection (Fig. 13) - Practised for incubated chicken eggs, an individual chick will be received a uniform dose of vaccine and help in developing early immunity against coccidiosis.

\section{1) Live Vaccines}

Live vaccines are comprised of either attenuated (precocious) or non-attenuated (virulent/wild-type) Eimeria strains, which help in developing the immunity of birds

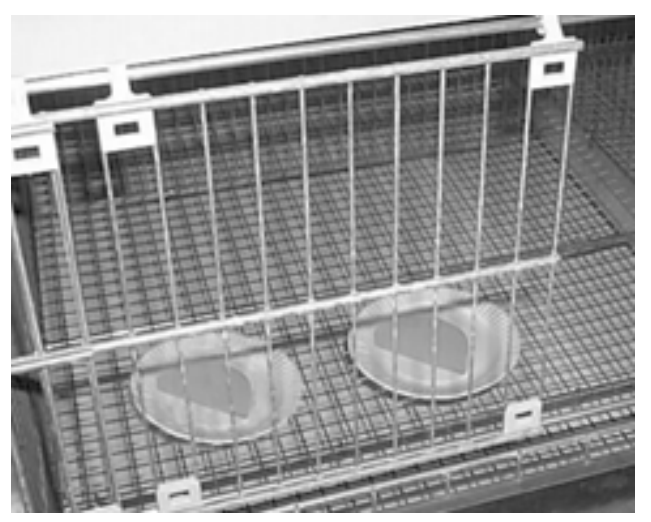

Fig. 12. Vaccine incorporated edible gel pucks (Retrieved from Soares et al., 2004).

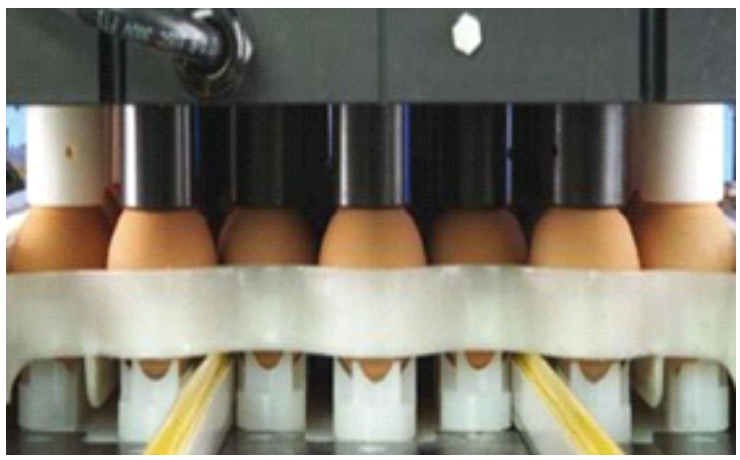

Fig. 13. In-ovo injection method (Retrieved from Alqomsan, 2010). 
against coccidiosis by recycling its lower dosage to a progeny (Quiroz-Castañeda and Dantán-González, 2015). Due to the risk of the direct introduction of live parasites to birds, live vaccines have been limited for broiler chickens in the past five decades, nonetheless, with the improved management and administration practises it is applying exponentially in present (Barbour et al., 2015). The use of live vaccines for preventing coccidiosis is upheld by the self-limiting nature of the Eimeria infection, less susceptibleness of younger chicks to the infection (development of immunity can easily occur through oocysts inoculation in the younger stage), and the development of immunity for different Eimeria spp. (McDonald and Shirley, 2009; Price, 2012). At present, live vaccines are proven to be more effective than anticoccidial drugs and there are several kinds of vaccines available in the world market for the sustainable control of coccidiosis in chickens which should be provided to chicks during the first week of age to have strong immunity against coccidiosis by faecal-oral recyclization of parasites (Danforth, 1998; Suo et al., 2006; Soutter et al., 2020). Nevertheless, the high cost of production, gradual decrement of pathogenicity of Eimeria spp. with time, tendency to reverse back to virulence, antigenic diversity, and errors in dosages are identified as major disadvantages of live vaccines (Peek and Landman, 2011).

Attenuated/precocious vaccines are produced by decreasing the virulence of Eimeria spp. strains artificially, either through a serial passage of the parasite in embryonated eggs, irradiation, chemical treatments, or by shortening the endogenous life-cycle of the parasite (precocity) by reducing one or more schizogony stages to produce a lower number of oocysts (Shivaramaiah et al., 2014; Abebe and Gugsa, 2018). Consequently, the lower pathogenic potential of the Eimeria parasites in attenuated vaccines (see Table 5) gives a mild infection and negligible intestinal damages to the bird with an

Table 5. Major anticoccidial vaccines in the global market

\begin{tabular}{|c|c|c|}
\hline Name of the vaccine & Type of the vaccine & Composition of the vaccine \\
\hline $\begin{array}{l}\text { Advent }{ }^{\circledR} \text { (Novus International Inc., St Charles, } \\
\text { MO, USA) }\end{array}$ & Non-attenuated & E. acervulina, E. maxima, E. tenella \\
\hline $\begin{array}{l}\text { Coccivac-B }^{\circledR} \text { (Merck Sharp and Dohme Ltd, } \\
\text { Whitehouse Station, NJ, USA) }\end{array}$ & Non-attenuated & E. acervulina, E. maxima, E. mivati, E. tenella \\
\hline $\begin{array}{l}\text { Coccivac-D }{ }^{\circledR} \text { (Merck Sharp and Dohme Ltd, NJ, } \\
\text { USA) }\end{array}$ & Non-attenuated & $\begin{array}{l}\text { E. acervulina, E. brunetti, E. hagani, E. maxima, E. } \\
\text { mivati, E. necatrix, E. praecox, E. tenella }\end{array}$ \\
\hline Immucox $\mathrm{THB}^{\circledR}$ (Vetech Laboratories, Canada) & Non-attenuated & E. acervulina, E. maxima, E. tenella, E. necatrix \\
\hline Immucox $\mathrm{C}^{\circledR}$ (Vetech Laboratories, Canada) & Non-attenuated & $\begin{array}{l}\text { E. acervulina, E. maxima, E. tenella, E. necatrix, E. } \\
\text { brunetti }\end{array}$ \\
\hline $\begin{array}{l}\text { Eimeriavax } 4 \mathrm{M}^{\circledR} \quad \text { (Bioproperties } \\
\text { Ringwood, Australia) }\end{array}$ & Attenuated & E. acervulina, E. maxima, E. necatrix, E. tenella \\
\hline $\begin{array}{l}\text { Inmuner } \text { Gel-Coc }^{\mathbb{B}} \quad \text { (Vacunas } \quad \text { Inmuner, } \\
\text { Argentina) }\end{array}$ & Attenuated & E. acervulina, E. maxima, E. tenella, E. brunetti \\
\hline Hipracox $^{\circledR}$ (Laboratorios Hipra, Spain) & Attenuated & $\begin{array}{l}\text { E. acervulina, E. maxima, E. tenella, E. praecox. E. } \\
\text { mitis }\end{array}$ \\
\hline Livacox $Q^{\circledR}$ (BioPharm, Czech Republic) & Attenuated & E. acervulina, E. maxima, E. necatrix, E. tenella \\
\hline Livacox $\mathrm{T}^{\mathbb{B}}$ (BioPharm, Czech Republic) & Attenuated & E. acervulina, E. maxima, E. tenella, \\
\hline $\begin{array}{l}\text { Eimerivac Plus (Guangdong Academy of } \\
\text { Agricultural Sciences, China) }\end{array}$ & Attenuated & E. acervulina, E. maxima, E. tenella \\
\hline Paracox $-5^{\circledR}$ (Merck Sharp and Dohme Ltd, UK) & Attenuated & E. acervulina, E. maxima, E. mitis, E. tenella \\
\hline Paracox- $-8^{\circledR}$ (Merck Sharp and Dohme Ltd, UK) & Attenuated & E. acervulina, E. maxima, E. mitis, E. brunetti \\
\hline CoxAbic $^{\circledR}$ (Abic Biological Laboratories, Israel) & Subunit & $\begin{array}{l}\text { Purified E. maxima antigens from microgametocyte } \\
\text { stages }\end{array}$ \\
\hline
\end{tabular}

Adapted from Shivaramaiah et al. (2014) and Peek and Landman (2011). 
effective immune response and reduced prepatent time (Allen and Fetterer 2002). However, lower fecundity of parasites will increase the cost of production of the attenuated vaccine and sometimes producers are failed to maintain the correct combination of the immunogenicity and attenuation of virulence of the parasites in the vaccine (Price, 2012). Besides, no artificial laboratory or field techniques are practised to alter the natural virulence/pathogenicity nature of Eimeria parasites in non-attenuated vaccines (Williams, 2002; Peek and Landman, 2011). Non-attenuated vaccines (Table 5) provide lifelong protective immunity to the birds against coccidiosis; however, the use is being limited due to the risk accompanied by the direct introduction of wild-type parasites to young birds which causes poor antigenic stimulation in the immune system (Lillehoj and Lillehoj, 2000; Quiroz-Castañeda and DantánGonzález, 2015). Moreover, it is necessary to provide the recommended dosage of non-attenuated vaccines to avoid vaccine-induced clinical coccidiosis from the birds (Peek and Landman, 2011).

\section{2) Recombinant Vectored Vaccines and Subunit Vaccines}

Instead of providing living parasites or their development stages, recombinant vectored vaccines are consisting immunogenic antigens of Eimeria spp. which are embedded in complementary plasmid vectors to stimulate the immunity of chickens against poultry coccidiosis (Fatoba and Adeleke, 2018; Suprihati et al., 2018). These types of vaccines have been considered safe for the host due to the attenuation of the vector organism during the development of the vaccine, and effective than live vaccines due to the lower production cost with higher efficacy (Shivaramaiah et al., 2014; Tan et al., 2017). Subunit vaccines (Table 5) are made out of either purified native gametocyte antigens of virulent Eimeria spp. or from their DNA recombinant proteins in different stages in the life cycle (i.e., sporozoites, merozoites or gametes) which develop humoral and cell-mediated immunity in chickens against coccidiosis infection (Peek and Landman, 2011; Barbour et al., 2015). Generally, the micronemes proteins (MIC) and protein secreted from the apical organelles of the Eimeria parasites (i.e., Apical membrane antigen 1, MITHB, MIC2, MIC3, MIC4 etc.) are considered as the anticoccidial vaccine candidates to produce recombinant vaccines (Shivaramaiah et al., 2014; Blake et al., 2017).

\section{Use of Anti-Coccidial Drugs}

Chemoprophylaxis has been deployed globally as an effective model for the prevention of coccidiosis by the inclusion of a range of anti-coccidial drugs into the poultry diet or drinking water, that provide coccidiostats effect (prevent the replication and growth) and coccidiocidal effect (destruction) upon Eimeria spp. (Chapman and Jeffers., 2014; Quiroz-Castañeda and Dantán-González, 2015). The majority of broad-spectrum anti-coccidial drugs inhibit the asexual phases (first and second), some of them are acting against the sexual phases of the Eimeria life cycle, and the least number of drugs hamper the chemical metabolic pathways of Eimeria spp. (Looker et al., 1986; Kant et al., 2013). Anti-coccidial drugs have reduced the treatment cost per bird significantly, increased the stocking density of birds in a single house, improved the quality of the end products, consequently, remained as the most popular coccidiosis treatment in larger poultry industries (Allen and Fetterer, 2002; Price, 2012). There are three major types of anti-coccidial drugs based on their origin and specific mode of action as follows (Allen and Fetterer, 2002; Peek and Landman, 2011):

1. Synthetic compounds

2. Ionophores/polyether antibiotics

3. An amalgamation of either two synthetic compounds (i.e., Meticlorpindol) or synthetic compounds and ionophore (i.e., Nicarbazin)

\section{1) Synthetic Compounds}

Chemically synthesized drugs (chemicals) that are capable of preventing coccidiosis infection are known as synthetic compounds (Peek and Landman, 2011). Sulphaquinoxaline, a sulphonamide chemical compound was first used as the anti-coccidial agent to prevent coccidiosis of poultry in 1948 (De Gussem, 2007). Those synthetic compounds diminish the Eimeria parasites in the host by either inhibiting their folate synthesis pathways, mitochondrial respiration, thiamin uptake or also through the unknown mode of actions (Noack et al., 2019). 
<smiles>COc1cc(NS(=O)(=O)c2ccc(N)cc2)nc(OC)n1</smiles>

(a)

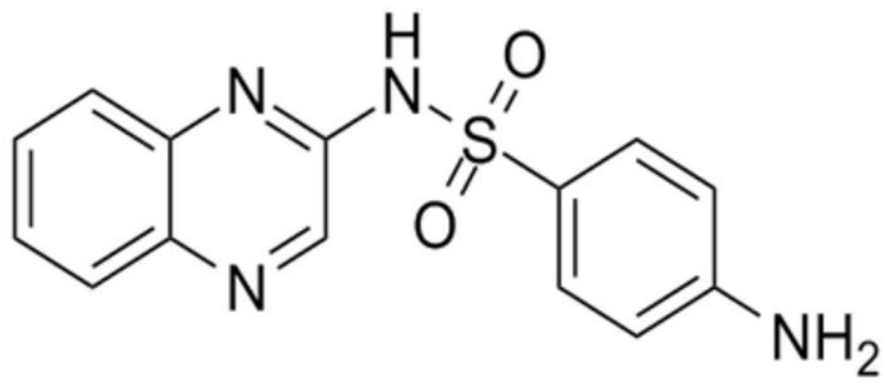

(b)

Fig. 14. Molecular structure of; (a) Sulfadimethoxine, (b) Sulfaquinoxaline (Public domain).

\section{(1) Sulfonamides (Sulfadimethoxine and Sulfaquinoxaline)}

Sulfonamides (Fig. 14) inhibit the cellular replication of the Eimeria parasite (especially in Eimeria brunetti and Eimeria maxima) by limiting the presence of para-aminobenzoic acid (PABA) which is known to be involved in the production of folic acid during the schizonts and sexual stages of the life cycle (Lebkowska-Wieruszewska and Kowalski, 2010; Peek and Landman, 2011).

\section{(2) Ethopabate}

The anti-coccidial activity of ethapobate (Fig. 15) is identical with the sulphonamides, as it interferes with PABA to inhibit the folate production of the parasite cell which is highly productive for Eimeria maxima and Eimeria brunetti (Peek and Landman, 2011; Noack et al., 2019).

\section{(3) Clopidol}

Clopidol (Fig. 16) is a complete coccidiostat that inhibits mitochondrial respiration and ATP formation in the early

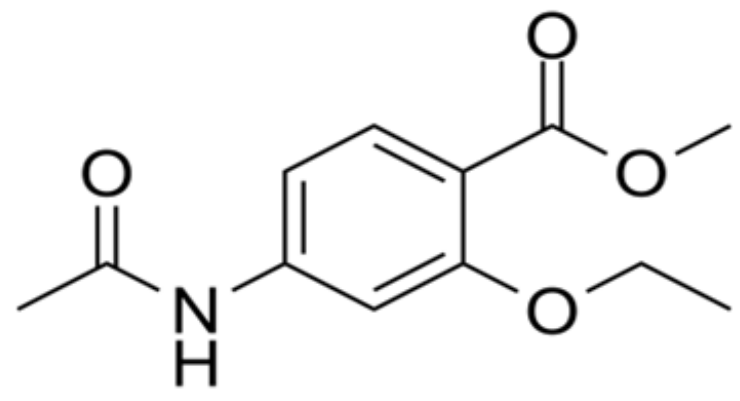

Fig. 15. Molecular structure of Ethopabate (Public domain).

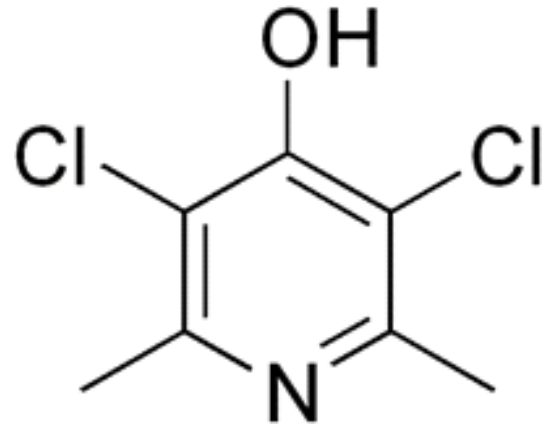

Fig. 16. Molecular structure of Clopidol (Public domain).

stages of Eimeria parasites (i.e., sporozoites and trophozoites) (Anon, 2010; Kant et al., 2013).

\section{(4) Quinolones}

Quinolone is a group of an artificially synthesized drugs (comprised of decoquinate and methyl benzoquate; Fig. 17) that inhibits mitochondrial respiration and ATP formation of the Eimeria parasites by altering the electron transportation system (Noack et al., 2019).

\section{(5) Amprolium Hydrochloride}

Amprolium hydrochloride (Fig. 18) is one of the safest synthetic anti-coccidial drugs used to act against the trophozoites and schizonts of Eimeria parasites (especially against E. acervulina, E. necatrix, E. tenella) and it leads to suppress the gametogenic stage and sporulation of the oocysts (Kant et al., 2013). Amprolium inhibits the production of thiamine pyrophosphate in Eimeria parasites by limiting the free thiamine (amprolium is a thiamine antagonist) that consequent in disturbed metabolic reactions (James, 1980; 


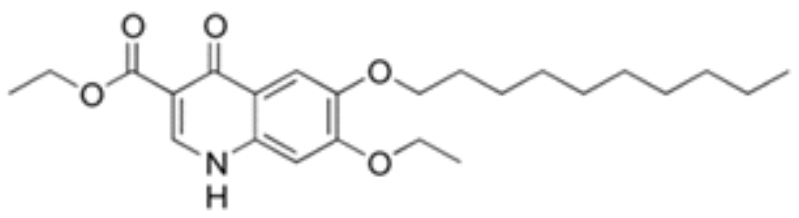

(a)<smiles>CCCCc1cc2c(=O)c(C(=O)OC)c[nH]c2cc1OCc1ccccc1</smiles>

(b)

(a)

(b)

Fig. 17. Molecular structure of; (a) Decoquinate, (b) Methyl benzoquate (Public domain).

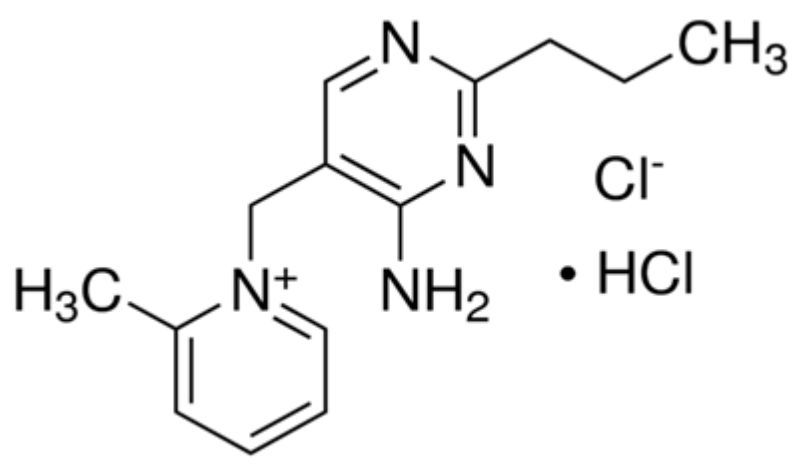

Fig. 18. Molecular structure of Amprolium hydrochloride (Public domain).

Noack et al., 2019).

\section{2) Ionophores/Polyether Antibiotics}

Ionophores/polyether antibiotics are lipid-soluble compounds (with multiple cyclic ether groups) mainly produced as a by-product from the fermentation process of Streptomyces spp. or Actinomadura spp. that elucidates coccidiocidal properties during the sexual and asexual stages of Eimeria life cycle (Shivaramaiah et al., 2014; Quiroz-Castañeda and DantánGonzález, 2015; Noack et al., 2019). Ionophores impair the vital transportation of metal cations and natural $\mathrm{Na} / \mathrm{K}$ concentration gradient across the cell membranes that amplifies the $\mathrm{Na}^{+}$and $\mathrm{Ca}^{2+}$ ion concentration in the parasite plasma. It leads to retarded development of sporozoites, as well as poor membrane integrity, increased osmotic pressure, elevated intracellular $\mathrm{pH}$, cytotoxicity and inhibition of substrate oxidation with ATP hydrolyzation in parasitic mitochondria that resulting in the eventual death of the cell (Kant et al., 2013; Antoszczak et al., 2019).
Despite the destruction of Eimeria parasites, polyether antibiotics develop the immunity of the host against coccidiosis with a slow rate of drug resistance as well as improved growth performance, thus considered the most effective and successful method to control coccidiosis in recent history (Chapman, 1999; Kala et al., 2014). Generally, three types of polyether antibiotics can be identified based on their structure, affinity towards cations, and transport rate capacity as follows (Dowling, 1992; Peek and Landman, 2011):

1. Monovalent ionophores (affinity towards monovalent cations)

2. Divalent ionophore (affinity towards divalent cations)

3. Monovalent glycosidic ionophores (no specific affinity towards monovalent or divalent cations) (see Table 6)

\section{Use of Phytogenic Compounds}

Phytogenic compounds/phytochemicals include the extensive range of plant-derived bioactive composites that have been used as prophylactic agents in improving the performance of chickens, as well as, eliminating coccidiosis or alleviating its deleterious effects (Shivaramaiah et al., 2014; Yang et al., 2015; Irivboje et al., 2020). Supplementation of phytochemicals to the poultry diet can be undertaken either as essential oils or herbal extracts, to provide antiparasitic, antimicrobial, antiviral, and antioxidative properties to the diet (Brenes and Roura, 2010; Puvača et al., 2013). At present, the usage of phytochemicals for preventing poultry coccidiosis have been promoted over the other traditional methods (i.e., vaccination, use of anti-coccidial drugs) due to 
Table 6. Major ionophores used for the prevention of coccidiosis in chicken

\begin{tabular}{|c|c|c|c|c|}
\hline Type of the ionophore & $\begin{array}{c}\text { Name of the ionophore and } \\
\text { molecular formula }\end{array}$ & Produced organism & Associated metal ions & References \\
\hline \multirow[t]{3}{*}{ Monovalent ionophores } & Salinomycin $\left(\mathrm{C}_{42} \mathrm{H}_{70} \mathrm{O}_{11}\right)$ & Streptomyces albus & $\mathrm{K}^{+}, \mathrm{Na}^{+}, \mathrm{Cs}^{+}$ & $\begin{array}{l}\text { Antoszczak et al. (2019), } \\
\text { Noack et al. (2019) }\end{array}$ \\
\hline & Monensin $\left(\mathrm{C}_{36} \mathrm{H}_{62} \mathrm{O}_{11}\right)$ & Streptomyces cinnamonensis & $\mathrm{Na}^{+}, \mathrm{K}^{+}, \mathrm{Rb}^{+}, \mathrm{Cs}^{+}, \mathrm{Li}^{+}$ & $\begin{array}{l}\text { Liu and Hermann (1978), } \\
\text { Rutkowski and Brzezinski } \\
\text { (2013) }\end{array}$ \\
\hline & Narasin $\left(\mathrm{C}_{43} \mathrm{H}_{72} \mathrm{O}_{11}\right)$ & Streptomyces aureofaciens & $\mathrm{K}^{+}, \mathrm{Na}^{+}$ & Jeffers et al. (1988) \\
\hline \multirow[t]{2}{*}{ Divalent ionophores } & Lasalocid $\left(\mathrm{C}_{34} \mathrm{H}_{54} \mathrm{O}_{8}\right)$ & Streptomyces lasaliensis & $\mathrm{Ba}^{+2}, \mathrm{Sr}^{+2}, \mathrm{Ca}^{+2}, \mathrm{Mg}^{+2}$ & $\begin{array}{l}\text { Rutkowski and Brzezinski } \\
\qquad \text { (2013) }\end{array}$ \\
\hline & Ionomycin $\left(\mathrm{C}_{41} \mathrm{H}_{70} \mathrm{CaO}_{9}\right)$ & Streptomyces conglobatus & $\mathrm{Ca}^{+2}, \mathrm{Mg}^{+2}, \mathrm{Ba}^{+2}, \mathrm{Sr}^{+2}$ & $\begin{array}{l}\text { Liu and Hermann (1978), } \\
\text { Antoszczak et al. (2019) }\end{array}$ \\
\hline \multirow[t]{2}{*}{$\begin{array}{l}\text { Monovalent glycosidic } \\
\text { ionophores }\end{array}$} & Maduramicin $\left(\mathrm{C}_{47} \mathrm{H}_{80} \mathrm{O}_{17}\right)$ & Actinomadura yumaensis & $\mathrm{Na}^{+}, \mathrm{Mg}^{+2}$ & $\begin{array}{l}\text { Liu et al. (1983), Gutiérrez } \\
\text { et al. (1999), Maron et al. } \\
\text { (2016), Noack et al. (2019) }\end{array}$ \\
\hline & Semduramicin $\left(\mathrm{C}_{45} \mathrm{H}_{76} \mathrm{O}_{16}\right)$ & Actinomadura roserufa & $\mathrm{Na}^{+}, \mathrm{Ca}^{+2}$ & $\begin{array}{l}\text { Dirlam et al. (1992), } \\
\text { Rychen et al. (2018) }\end{array}$ \\
\hline
\end{tabular}

Table 7. Examples of frequently used anti-coccidial phytogenic components and their respective plants

\begin{tabular}{|c|c|c|}
\hline Bioactive compound/s name & Principle plant species/s & References \\
\hline \multirow[t]{3}{*}{ Carvacrol } & Origanum vulgare & Alagawany et al. (2015) \\
\hline & Thymus vulgare & Alagawany et al. (2015) \\
\hline & Lepidium flavum & Alagawany et al. (2015) \\
\hline Thymol & Thymus vulgare & Yitbarek (2015) \\
\hline \multirow[t]{3}{*}{ 3,4,5-trihydroxybenzoic acid } & Rheum officinale & Zhang et al. (2018) \\
\hline & Eucalyptus robusta Smith & Zhang et al. (2018) \\
\hline & Semen corni & Zhang et al. (2018) \\
\hline Gingerdoine, Gengerdiol and Gingerol & Zingiber officinale & Ali et al. (2019) \\
\hline Diallyl disulfide, Alliin and Alliciin & Allium sativum & Ali et al. (2019) \\
\hline Eugenol & Syzygium aromaticum & Evans et al. (2001) \\
\hline Menthol & Mentha $x$ piperita $\mathrm{L}$. & Evans et al. (2001) \\
\hline Anethol & Pimpinella anisum & Yitbarek (2015) \\
\hline Cinnamaldehyde & Cinnamomum verum & Orengo et al. (2012) \\
\hline Betaine & Beta vulgaris sp. & Kumar et al. (2014) \\
\hline Curcumin & Curcuma longa & Kumar et al. (2014) \\
\hline
\end{tabular}

its safe nature, no development of drug resistance and no drug residual accumulation in the host that certified a safe end product to the consumer (Abbas et al., 2012; Allouiet et al., 2014; Giannenas et al., 2014). Several authors have identified a great number of phytogenics to act against
Eimeria spp. in poultry and frequently used compounds are mentioned in Table 7.

\section{ORCID}

Shan Randima Nawarathne 
https://orcid.org/0000-0001-9055-9155

Myunghwan $\mathrm{Yu}$

https://orcid.org/0000-0003-4479-4677

Jung Min Heo

\section{ACKNOWLEDGMENTS}

This work was carried out with the support of "Cooperative Research Program for Agriculture Science and Technology Development (Project No. PJ014162032021)” Rural Development Administration, Republic of Korea.

\section{REFERENCES}

Abbas RZ, Iqbal Z, Khan A, Sindhu ZUD, Khan JA, Khan MN, Raza A 2012 Options for integrated strategies for the control of avian coccidiosis. Int J Agric Biol 14(6):1014-1020.

Abdisa T, Hasen R, Tagesu T, Regea G, Tadese G 2019 Poultry coccidiosis and its prevention, controls. Ani Vet J 2(1):1-6.

Abebe E, Gugsa G 2018 A review on poultry coccidiosis. Abyss J Sci Technol 3(1):1-12.

Abo Alqomsan HM 2010 Prevalence of caecal coccidiosis among broilers in Gaza strip. Ph. D. Dissertation, Gaza. Pages 1-78. In: Islamic University-Gaza.

Absher M 1973 Hemocytometer counting. Pages 395-397 In: Tissue Culture. Paul F, Kruse MK, Patterson (Eds), Academic Press.

Abunemeh M 2016 Methods of Quantification and Characterization of Coccidian Oocysts. Pages 1-35. BA In: Biology Dissertation, University of Mississippi.

Alagawany M, El-Hack M, Farag MR, Tiwari R, Dhama K 2015 Biological effects and modes of action of carvacrol in animal and poultry pro-duction and health-A review. Adv Anim Vet Sci 3(2):73-84.

Albanese GA, Tensa LR, Aston EJ, Hilt DA, Jordan BJ 2018 Evaluation of a coccidia vaccine using spray and gel applications. Poult Sci J 97(5):1544-1553.

Ali M, Chand N, Khan RU, Naz S, Gul S 2019 Anticoccidial effect of garlic (Allium sativum) and ginger (Zingiber officinale) against experimentally induced coccidiosis in broiler chickens. J Appl Anim Res 47(1):79-84.

Allen PC, Fetterer R 2002 Recent advances in biology and

immunobiology of Eimeria species and in diagnosis and control of infection with these coccidian parasites of poultry. Clin Microbiol Rev 15(1):58-65.

Alloui MN, Agabou A, Alloui N 2014 Application of herbs and phytogenic feed additives in poultry production-A Review. Glob J Anim Sci Res 2(3):234-243.

Antoszczak M, Steverding D, Huczyński A 2019 Anti-parasitic activity of polyether ionophores. Eur J Med Chem 166: $32-47$.

Arabkhazaeli F, Nabian S, Modirsaneii M, Mansoori B, Rahbari S 2011 Biopathologic characterization of three mixed poultry Eimeria spp. isolates. Iran J Parasitol 6(4):23-32.

Asfaw YT, Ameni G, Medhin G, Gumi B, Hagos Y, Wieland B 2021 Poultry disease occurrences and their impacts in Ethiopia. Trop Anim Health Prod 53(1):1-10.

Attia YA, Al-Harthi MA, Korish MA, Shiboob MM 2017 Fatty acid and cholesterol profiles, hypocholesterolemic, atherogenic, and thrombogenic indices of broiler meat in the retail market. Lipids Health Dis 16(1):1-11.

Barbour E, Ayyash D, Iyer A, Harakeh S, Kumosani T 2015 A review of approaches targeting the replacement of coccidiostat application in poultry production. Rev Bras Cienc Avic 17(4):405-418.

Belli SI, Smith NC, Ferguson DJ 2006 The coccidian oocyst: a tough nut to crack! Trends Parasitol 22(9):416-423.

Benesh DP 2016 Autonomy and integration in complex parasite life cycles. Parasitology 143(14):1824-1846.

Blake DP, Pastor-Fernández I, Nolan MJ, Tomley FM 2017 Recombinant anticoccidial vaccines-a cup half full? Infect Genet Evol 55:358-365.

Blake DP, Tomley FM 2014 Securing poultry production from the ever-present Eimeria challenge. Trends Parasitol 30(1):12-19.

Blake DP, Worthing K, Jenkins MC 2020 Exploring Eimeria genomes to understand population biology: recent progress and future opportunities. Genes 11(9):1103-1117.

Brenes A, Roura E 2010 Essential oils in poultry nutrition: main effects and modes of action. Anim Feed Sci Technol 158(1-2):1-14.

Canning EU, Anwar M 1968 Studies on meiotic division in coccidial and malarial parasites. J Protozool 15(2):290-298. 
Cantacessi C, Riddell S, Morris GM, Doran T, Woods WG, Otranto D, Gasser RB 2008 Genetic characterization of three unique operational taxonomic units of Eimeria from chickens in Australia based on nuclear spacer ribosomal DNA. Vet Parasitol 152(3-4):226-234.

Chang HS 2007 Overview of the world broiler industry: implications for the Philippines. Asian J Agric Dev $4(2): 67-82$.

Chapman H 1999 Anticoccidial drugs and their effects upon the development of immunity to Eimeria infections in poultry. Avian Pathol 28(6):521-535.

Chen HL, Zhao XY, Zhao GX, Huang HB, Li HR, Shi CW, Yang WT, Jiang YL, Wang JZ, Ye LP 2020 Dissection of the cecal microbial community in chickens after Eimeria tenella infection. Parasit Vectors 13(1):1-15.

Chilton NB 1999 Multilocus enzyme electrophoresis: a valuable technique for providing answers to problems in parasite systematics. Int J Parasitol 29(2):213-253.

Collier C, Hofacre C, Payne A, Anderson D, Kaiser P, Mackie R, Gaskins H 2008 Coccidia-induced mucogenesis promotes the onset of necrotic enteritis by supporting Clostridium perfringens growth. Vet Immunol Immunopathol 122(1-2):104-115.

Constantinoiu C, Molloy J, Jorgensen W, Coleman G 2007 Development and validation of an ELISA for detecting antibodies to Eimeria tenella in chickens. Vet Parasitol 150(4):306-313.

Conway DP, McKenzie ME 2007 Poultry Coccidiosis: Diagnostic and Testing Procedures. 3rd ed. Blackwell Publishing, State Avenue, Iowa, USA.

Dakpogan HB, Salifou S 2013 Coccidiosis prevalence and intensity in litter based high stocking density layer rearing system of Benin. J Anim Plant Sci 17(2):2522-2526.

Danforth H 1998 Use of live oocyst vaccines in the control of avian coccidiosis: experimental studies and field trials. Int J Parasitol 28(7):1099-1109.

De Gussem M 2007 Coccidiosis in poultry: review on diagnosis, control, prevention and interaction with overall gut health. Pages 253-261. In: Proceedings of the 16th European Symposium on Poultry Nutrition.

Deplazes P, Eckert J, Mathis A, Samson-Himmelstjerna GV, Zahner H 2016 Parasitology in veterinary medicine. Pages
1-650 In: Parasitology in Veterinary Medicine. Wageningen Academic Publishers, Netherland.

Dirlam JP, Bordner J, Chang SP, Grizzuti A, Nelson TH, Tynan EJ, Whipple EB 1992 The isolation and structure of CP-120, 509, A new polyether antibiotic related to semduramicin and produced by mutants of Actinomadura roseorufa. J Antibiot 45(9):1544-1548.

Dowling L 1992 Ionophore toxicity in chickens: a review of pathology and diagnosis. Avian Pathol 21(3):355-368.

El-Tonsy MM 2012 Introduction to medical parasitology. In: Medical Sciences, Kotchetkov V (Eds.), Encyclopaedia of Life Support System 53.

Ellis J, Bumstead J 1990 Eimeria species: studies using rRNA and rDNA probes. Parasitology 101(1):1-6.

Evans J, Plunkett M and Banfield M 2001 Effect of an essential oil blend on coccidiosis in broiler chicks. Poult Sci $80 \mathrm{~S}: 258$

Fanatico A 2006 Parasite Management for Natural and Organic Poultry: coccidiosis. ATTRA Publication. Fayetteville, AR.

Fatoba AJ, Adeleke MA 2018 Diagnosis and control of chicken coccidiosis: a recent update. J Parasit Dis 42(4):483-493.

Fernandez S, Costa A, Katsuyama A, Madeira A, Gruber A 2003 A survey of the inter-and intraspecific RAPD markers of Eimeria spp. of the domestic fowl and the development of reliable diagnostic tools. Parasitol Res 89(6):437-445.

Fitz-Coy S, Edgar S 1992 Pathogenicity and control of Eimeria mitis infections in broiler chickens. Avian Dis 36:44-48.

Garcia LS, Arrowood M, Kokoskin E, Paltridge GP, Pillai DR, Procop GW, Ryan N, Shimizu RY, Visvesvara G 2018 Practical guidance for clinical microbiology laboratories: laboratory diagnosis of parasites from the gastrointestinal tract. Clin Microbiol Rev 31(1):1-81.

Gharekhani J, Sadeghi-Dehkordi Z, Bahrami M 2014 Prevalence of coccidiosis in broiler chicken farms in Western Iran. J Vet Med 2014:1-4.

Giannenas I, Papaneophytou C, Tsalie E, Pappas I, Triantafillou E, Tontis D, Kontopidis G 2014 Dietary supplementation of benzoic acid and essential oil compounds affects buffering capacity of the feeds, performance of turkey poults and their antioxidant status, $\mathrm{pH}$ in the digestive tract, intestinal 
microbiota and morphology. Asian-Australas J Anim Sci 27(2):225-236.

Graat E, Ploeger H, Henken A, Reilingh GDV, Noordhuizen

J, Van Beek P 1996 Effects of initial litter contamination level with Eimeria acervulina on population dynamics and production characteristics in broilers. Vet Parasitol 65(3-4):223-232.

Singla LD, Gupta SK 2012 Advances in diagnosis of coccidiosis in poultry. Pages 615-628 In: Veterinary Diagnostics. Current Trends, Gupta RP, Garg SR, Nehra V and Lather D (Eds). Satish Serial Publishing House, Delhi.

Gutiérrez-Lugo MT, Lotina-Hennsen B, Farrés A, Sánchez S, Mata R 1999 Phytotoxic and photosynthetic activities of maduramicin and maduramicin methyl ester. Z Naturforsch C J Biosci 54(5-6):325-332.

Hadipour MM, Olyaie A, Naderi M, Azad F, Nekouie O 2011 Prevalence of Eimeria species in scavenging native chickens of Shiraz, Iran. Afr J Microbiol Res 5(20): 3296-3299.

Hafez HM, Attia YA 2020 Challenges to the poultry industry: current perspectives and strategic future after the COVID-19 outbreak. Front Vet Sci 7:1-16.

Hamidinejat H, Shapouri MS, Mayahi M, Borujeni MP 2010 Characterization of Eimeria species in commercial broilers by PCR based on ITS1 regions of rDNA. Iran J Parasitol 5(4):48-54.

Irivboje OA, Olufayo O, Irivboje YI 2020 Phytogenic compounds: a review of ginger and garlic as an alternative feed additive in poultry nutrition. In: Proceedings of 25 th Annual Conference of ASAN 2020, Abuja, Nigeria:299-302.

Izar-Tenorio J, Jaramillo P, Griffin WM, Small M 2020 Impacts of projected climate change scenarios on heating and cooling demand for industrial broiler chicken farming in the Eastern US. J Clean Prod 255:120306-120314.

James S 1980 Thiamine uptake in isolated schizonts of Eimeria tenella and the inhibitory effects of amprolium. Parasitology 80(2):313-322.

Jeffers T, Tonkinson L, Callender M 1988 Anticoccidial efficacy of narasin in battery cage trials. Poult Sci 67(7):1043-1049.

Johnson J, Reid WM 1970 Anticoccidial drugs: lesion scoring techniques in battery and floor-pen experiments with chickens. Exp Parasitol 28(1):30-36.

Johnson WT 1938 Coccidiosis of the chicken with special reference to species. Station Bulletin 358:1-33.

Kala S, Gattani A, Kumar A, Samantaray S 2014 Evaluation of polyether ionophores against coccidiosis in broiler chicken. Haryana Vet 52(1):63-67.

Kant V, Singh P, Verma PK, Bais I, Parmar MS, Gopal A, Gupta V 2013 Anticoccidial drugs used in the poultry: an overview. Sci Int 1(7):261-265.

Kaufman PE, Koehler PG, Butler JF 2006 External parasites of poultry. Published by Entomology and Nematology Department, Florida Cooperative Extension Service, Institute of Food and Agricultural Sciences, University of Florida:1-13.

Kaufmann J 1996 Parasitic Infections of Domestic Animals: A Diagnostic Manual. Pages 1-423, Switzerland.

Kim WH, Chaudhari AA, Lillehoj HS 2019 Involvement of $\mathrm{T}$ cell immunity in avian coccidiosis. Front Immunol 10(2732):1-8.

Kumar M, Kumar V, Roy D, Kushwaha R, Vaiswani S 2014 Application of herbal feed additives in animal nutrition-A review. Int $\mathrm{J}$ Lives Res 4:1-8.

Lal K, Bromley E, Oakes R, Prieto JH, Sanderson SJ, Kurian D, Hunt L, Yates III JR, Wastling JM, Sinden RE 2009 Proteomic comparison of four Eimeria tenella life cycle stages: unsporulated oocyst, sporulated oocyst, sporozoite and second generation merozoite. Proteomics 9(19):4566-4576.

Lawal JR, Jajere SM, Ibrahim UI, Geidam YA, Gulani IA, Musa G, Ibekwe BU 2016 Prevalence of coccidiosis among village and exotic breed of chickens in Maiduguri, Nigeria. Vet World 9(6):653-659.

Łebkowska Wieruszewska BI, Kowalski C 2010 Sulfachlorpyrazine residues depletion in turkey edible tissues. J Vet Pharmacol Ther 33(4):389-395.

Lee S, Lillehoj H, Park D, Jang S, Morales A, García D, Lucio E, Larios R, Victoria G, Marrufo D 2009 Induction of passive immunity in broiler chickens against Eimeria acervulina by hyperimmune egg yolk immunoglobulin Y. Poult Sci 88(3):562-566.

Levine ND 1961 Protozoan Parasites of Domestic Animals and of Man. Burgess Pub. Co., Minneapolis, Minn. 
Lew A, Anderson G, Minchin C, Jeston P, Jorgensen W 2003 Inter-and intra-strain variation and PCR detection of the internal transcribed spacer 1 (ITS-1) sequences of Australian isolates of Eimeria species from chickens. Vet Parasitol 112(1-2):33-50.

Lillehoj HS, Lillehoj EP 2000 Avian coccidiosis. A review of acquired intestinal immunity and vaccination strategies. Avian Dis 44:408-425.

Liu CM, Hermann T, Downey A, Prosser BLT, Schildknecht E, Palleroni N, Westley J, Miller P 1983 Novel polyether antibiotics X-14868A, B, C, and D produced by a nocardia discovery, fermentation, biological as well as ionophore properties and taxonomy of the producing culture. J Antibiot 36(4):343-350.

Liu C, Hermann TE 1978 Characterization of ionomycin as a calcium ionophore. J Biol Chem 253(17):5892-5894.

Looker DL, Marr JJ, Stotish RL 1986 Modes of action of antiprotozoal agents. Pages 193-207. In: Chemotherapy of Parasitic Diseases. Campbell WC, Rew RS (Eds), Springer, Springer Nature Switzerland.

López-Osorio S, Chaparro-Gutiérrez JJ, Gómez-Osorio LM 2020 Overview of poultry Eimeria life cycle and host-parasite interactions. Front Vet Sci 7(384):1-8.

Mai K, Sharman PA, Walker RA, Katrib M, Souza DD, McConville MJ, Wallach MG, Belli SI, Ferguson DJ, Smith NC 2009 Oocyst wall formation and composition in coccidian parasites. Mem Inst Oswaldo Cruz 104:281-289.

Maron MI, Magle CT, Czesny B, Turturice BA, Huang R, Zheng W, Vaidya AB, Williamson KC 2015 Maduramicin rapidly eliminates malaria parasites and potentiates the gametocytocidal activity of the pyrazoleamide PA21A050. Antimicrob Agents Ch 60(3):1492-1499.

McDonald V, Shirley M 2009 Past and future: vaccination against Eimeria. Parasitology 136(12):1477-1489.

Morris G, Gasser R 2006 Biotechnological advances in the diagnosis of avian coccidiosis and the analysis of genetic variation in Eimeria. Biotechnol Adv 24(6):590-603.

Mwale M, Masika PJ 2011 Point prevalence study of gastro-intestinal parasites in village chickens of Centane district, South Africa. Afr J Agric Res 6(9):2033-2038.

Nnadi P, George S 2010 A cross-sectional survey on parasites of chickens in selected villages in the subhumid zones of South-Eastern Nigeria. Parasitol Res 2010:1-6.

Noack S, Chapman HD, Selzer PM 2019 Anticoccidial drugs of the livestock industry. Parasitol Res 118(7):2009-2026.

Olanrewaju CA, Agbor RY 2014 Prevalence of coccidiosis among poultry birds slaughtered at Gwagwalada main market, Abuja, FCT, Nigeria. Int J Eng Sci 3(1):41-45.

Onaga H, Saeki H, Hoshi S, Ueda S 1986 An enzyme-linked immunosorbent assay for serodiagnosis of coccidiosis in chickens: use of a single serum dilution. Avian Dis 30:658-661.

Orengo J, Buendía A, Ruiz-Ibáñez M, Madrid J, Del Río L, Catalá-Gregori P, García V, Hernández F 2012 Evaluating the efficacy of cinnamaldehyde and Echinacea purpurea plant extract in broilers against Eimeria acervulina. Vet Parasitol 185(2-4):158-163.

Pattison M, McMullin P, Bradbury JM, Alexander D 2007 Parasitic diseases: Coccidiosis. Pages 444-456 In: Poultry Diseases. Elsevier Limited, Elsevier's Health Sciences Rights Department, 1600 John F. Kennedy Boulevard, Philadelphia.

Peek H, Landman W 2011 Coccidiosis in poultry: anticoccidial products, vaccines and other prevention strategies. Vet $\mathrm{Q}$ 31(3):143-161.

Pereckienė A, Kaziūnaitè V, Vyšniauskas A, Petkevičius S, Malakauskas A, Šarkūnas M, Taylor M 2007 A comparison of modifications of the McMaster method for the enumeration of Ascaris suum eggs in pig faecal samples. Vet Parasitol 149(1-2):111-116.

Permin A, Hansen JW 1998. Epidemiology, diagnosis and control of poultry parasites. Pages 1-154 In: FAO Manual, Food and Agriculture Organization of the United Nations, Rome.

Petracci M, Soglia F, Madruga M, Carvalho L, Ida E, Estévez M 2019 Wooden breast, white striping, and spaghetti meat: causes, consequences and consumer perception of emerging broiler meat abnormalities. Compr Rev Food Sci Food Saf 18(2):565-583.

Poulin R 2014 Parasite biodiversity revisited: frontiers and constraints. Int J Parasitol 44(9):581-589.

Pouta E, Heikkilä J, Forsman-Hugg S, Isoniemi M, Mäkelä J 2010 Consumer choice of broiler meat: the effects of country of origin and production methods. Food Qual 
Prefer 21(5):539-546.

Price K 2012 Use of live vaccines for coccidiosis control in replacement layer pullets. J Appl Poult Res 21(3):679-692.

Puvača N, Stanaćev V, Glamočić D, Lević J, Perić L, Milić D 2013 Beneficial effects of phytoadditives in broiler nutrition. Worlds Poult Sci J 69(1):27-34.

Quiroz-Castañeda RE, Dantán-González E 2015 Control of avian coccidiosis: future and present natural alternatives. Biomed Res. Int. 2015:1-11.

Reid WM 1990 History of avian medicine in the United States. X. Control of coccidiosis. Avian Dis 34(3):509-525.

Remmal A, Achahbar S, Bouddine L, Chami N, Chami F 2011 In vitro destruction of Eimeria oocysts by essential oils. Vet Parasitol 182(2-4):121-126.

Répérant JM, Dardi M, Pagès M, Thomas-Hénaff M 2012 Pathogenicity of Eimeria praecox alone or associated with Eimeria acervulina in experimentally infected broiler chickens. Vet Parasitol 187(1-2):333-336.

Ruff MD 1999 Important parasites in poultry production systems. Vet Parasitol 84(3-4):337-347.

Rutkowski J, Brzezinski B 2013 Structures and properties of naturally occurring polyether antibiotics. Biomed Res Int 2013:1-31.

Rychen G, Aquilina G, Azimonti G, Bampidis V, Bastos MdL, Bories G, Chesson A, Cocconcelli PS, Flachowsky G 2018 Scientific opinion on the safety and efficacy of Aviax 5\% (semduramicin sodium) for chickens for fattening. EFSA Journal 16(7):1-42.

Schnitzler BE, Thebo PL, Mattsson JG, Tomley FM, Shirley MW 1998 Development of a diagnostic PCR assay for the detection and discrimination of four pathogenic. Eimeria species of the chicken. Avian Pathol 27(5):490-497.

Sharman PA, Smith NC, Wallach MG, Katrib M 2010 Chasing the golden egg: vaccination against poultry coccidiosis. Parasite Immunol 32(8):590-598.

Shirley M, Harvey D 1996 Eimeria tenella: infection with a single sporocyst gives a clonal population. Parasitology 112(6):523-528.

Shirley M, Lillehoj H 2012 The long view: a selective review of 40 years of coccidiosis research. Avian Pathol 41(2):111-121.

Shirley MW, Smith AL, Tomley FM 2005 The biology of avian Eimeria with an emphasis on their control by vaccination. Adv Parasitol 60:285-330.

Shivaramaiah C, Barta JR, Hernandez-Velasco X, Téllez G, Hargis BM 2014 Coccidiosis: recent advancements in the immunobiology of Eimeria species, preventive measures, and the importance of vaccination as a control tool against these Apicomplexan parasites. Vet Med: Research and Reports 5:23-34.

Smith N, Bucklar H, Muggli E, Hoop R, Gottstein B, Eckert J 1993 Use of IgG-and IgM-specific ELISAs for the assessment of exposure status of chickens to Eimeria species. Vet Parasitol 51(1-2):13-25.

Soares R, Cosstick T, Lee E 2004 Control of coccidiosis in caged egg layers: a paper plate vaccination method. Appl Poult Res 13(2):360-363.

Sokale A, Zhai W, Pote L, Williams C, Peebles E 2017 Effects of coccidiosis vaccination administered by in ovo injection on the hatchability and hatching chick quality of broilers. Poult Sci 96(3):541-547.

Soutter F, Werling D, Tomley FM, Blake DP 2020 Poultry coccidiosis: design and interpretation of vaccine studies. Front Vet Sci 7(101):1-12.

Stanley D, Wu SB, Rodgers N, Swick RA, Moore RJ 2014 Differential responses of cecal microbiota to fishmeal, Eimeria and Clostridium perfringens in a necrotic enteritis challenge model in chickens. PLOS ONE e104739 9(8):1-10.

Su YC, Fei ACY, Tsai FM 2003 Differential diagnosis of five avian Eimeria species by polymerase chain reaction using primers derived from the internal transcribed spacer 1 (ITS-1) sequence. Vet Parasitol 117(3):221-227.

Suo X, Zhang J, Li Z, Yang C, Min Q, Xu L, Liu Q, Zhu X 2006 The efficacy and economic benefits of Supercox ${ }^{\circledR}$, a live anticoccidial vaccine in a commercial trial in broiler chickens in China. Vet Parasitol 142(1-2):63-70.

Suprihati E, Yunus M 2018 Evaluation of the antigenicity and immunogenicity of Eimeria tenella by reproductive index and histopathological changes of cecal coccidiosis virulent live vaccine in broiler chickens. Afr $\mathrm{J}$ Infect Dis 12(1S):104-110.

Taliaferro W 2009 Basic Principles and Concepts I: Parasite Systematics, Ecology, and Evolution (Chapter 2). 8th ed. Pages 11-24 In: Foundation of Parasitology. Roberts LS 
and Ovy JR. (ed). Boston Burr Ridge, IL Dubuque, IA New York, San Francisco.

Tan L, Li Y, Yang X, Ke Q, Lei W, Mughal MN, Fang R, Zhou Y, Shen B, Zhao J 2017 Genetic diversity and drug sensitivity studies on Eimeria tenella field isolates from Hubei Province of China. Parasites Vectors 10(1):1-10.

Uchida T, Nakamura T, Nakai Y, Ogimoto K 1994 Cross reactivity of serum antibodies from chickens immunized with three Eimerian species. J Vet Med Sci 56(5):1021-1023.

Vadlejch J, Petrtýl M, Zaichenko I, Čadková Z, Jankovská I, Langrová I, Moravec M 2011 Which McMaster egg counting technique is the most reliable? Parasitol Res 109(5):1387-1394.

Vegad J 2007 A Colour Atlas of Poultry Diseases -An Aid to Farmers and Poultry Professionals. International Book Distributing Company, Charbagh, Lucknow. Charbagh, Lucknow.

Wallach M 2010 Role of antibody in immunity and control of chicken coccidiosis. Trends Parasitol 26(8):382-387.

Wideman N, O'bryan C, Crandall P 2016 Factors affecting poultry meat colour and consumer preferences-A review. Worlds Poult Sci J 72(2):353-366.

Williams R 2002 Anticoccidial vaccines for broiler chickens: pathways to success. Avian Pathol 31(4):317-353.

Williams R, Johnson J, Andrews S 2000 Anticoccidial vaccination of broiler chickens in various management programmes: relationship between oocyst accumulation in litter and the development of protective immunity. Vet. Res. Commun 24(5):309-325.

Wubet W, Bitew M, Mamo G, Gelaye E, Tesfaw L, Sori H, Zewdie T, Abayneh T 2019 Evaluation of inactivated vaccine against fowl cholera developed from local isolates of Pasteurella multocida in Ethiopia. Afr J Microbiol Res 13(27):500-509.

Yang C, Chowdhury M, Huo Y, Gong J 2015 Phytogenic compounds as alternatives to in-feed antibiotics: potentials and challenges in application. Pathogens 4(1):137-156.

Yegani M, Korver D 2008 Factors affecting intestinal health in poultry. Poult Sci J 87(10):2052-2063.

Yitbarek MB 2015 Phytogenics as feed additives in poultry production: a review. Int J Extensive Res 3:49-60.

Zhang J, Li B, Yue H, Wang J, Zheng Y 2018 Highly selective and efficient imprinted polymers based on carboxyl functionalized magnetic nanoparticles for the extraction of gallic acid from pomegranate rind. J Sep Sci 41(2):540-547.

Received Oct. 1, 2021, Revised Dec. 23, 2021, Accepted Dec. 24, 2021 